مجلة العلوم البيئية

معهد الدراسات والبحوث البيئية - جامعة عين شمس لبئه

احمد احمد عبد القدوس وآخرون

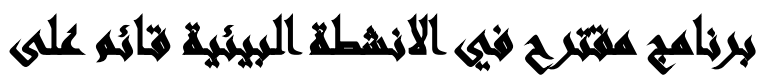

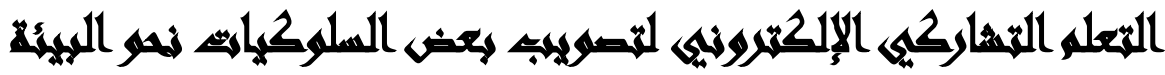

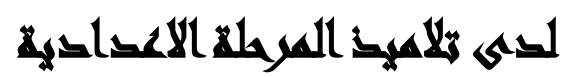

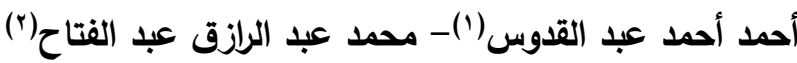

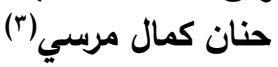

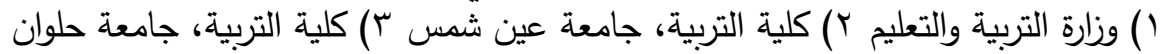

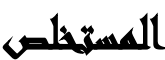

هََفَ البحث الحالي إلى تصويب بعض السلوكيات غير الرشيدة نحو البيئة من خلال

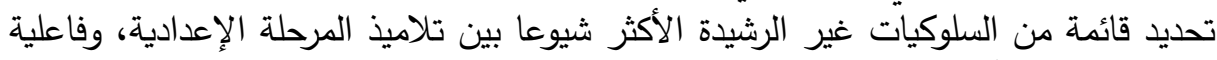

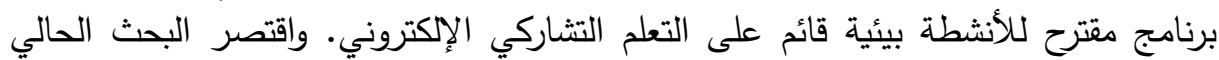

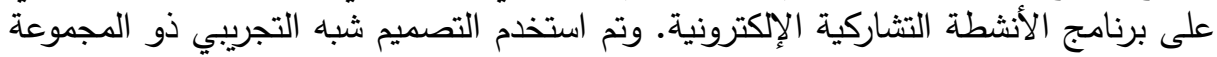

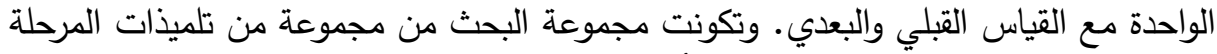

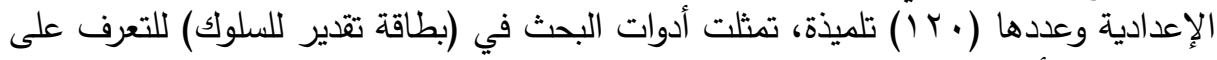

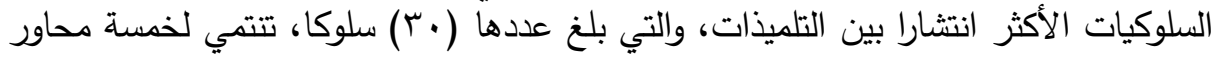

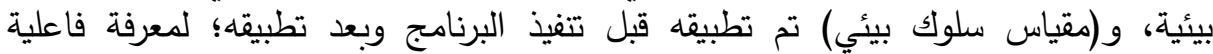

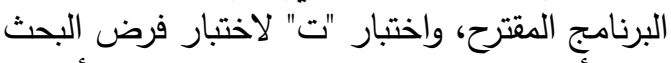

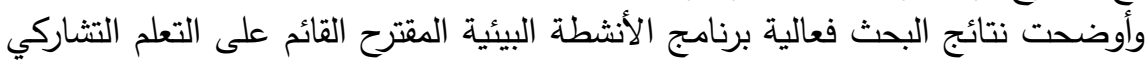

$$
\text { الإلكتروني في تصويب بعض السلوكيات تجاه البيئة. }
$$

وأوصى البحث بضرورة استخدام بيئة التعلم الإلكتروني التثاركي في المبئة المواد الدراسية

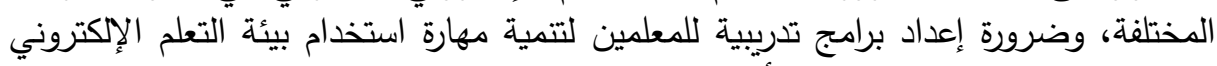

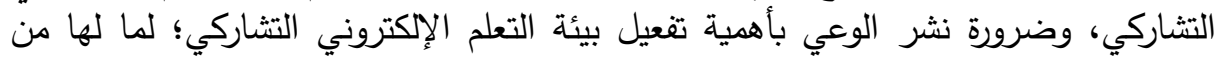

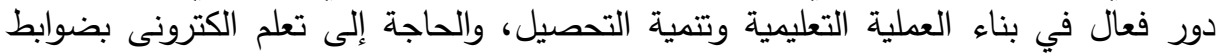

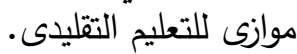

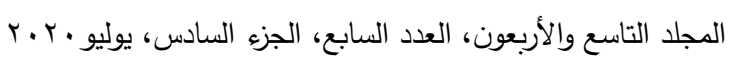

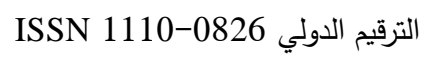


مجلة العلوم البيئية

معهد الدراسات والبحوث البيئية - جامعة عين شمس لهـ آله

احمد احمد عبد القدوس وآخرون

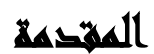

أدى التطور الحادث في مجال المعلومات ونظم الثبكات والاتصالات إلى تغير واضح

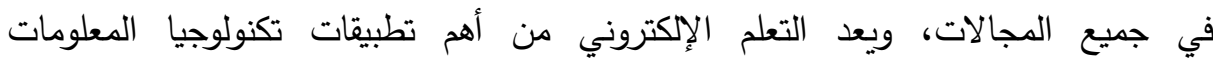
والاتصالات في مجال التعليم، حيث يقوم أساساً على ما توفره هذه التكنولوجيا من أدوات التهني

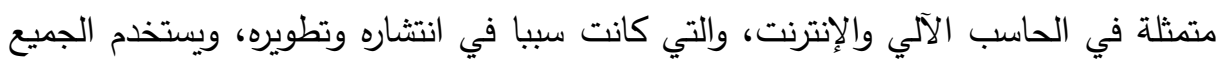
الوسائط المتعددة في تدفق المعلومات في المجالات المختلفة لتسهيل استيعاب الطالب وفهمه للمادة العلمية وفق قدراته وفي أي وقت شاء (العطروزى، ب . . r).

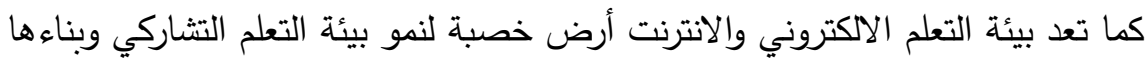

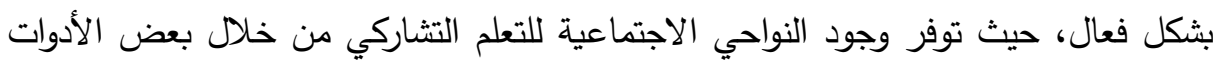
المتاحة التي تتسم بالتثاركية والتي يمكن استغلالها وتوظيفها. (Gewertz, 2012)

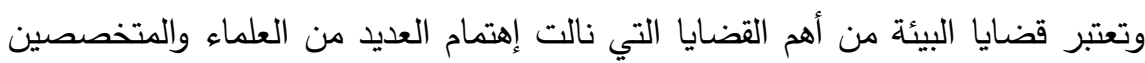

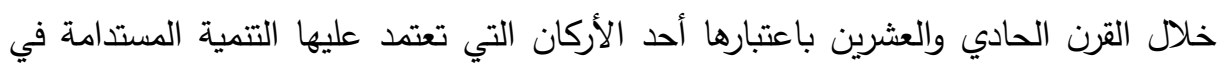

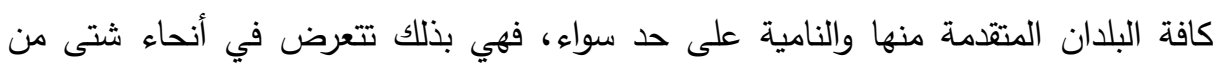

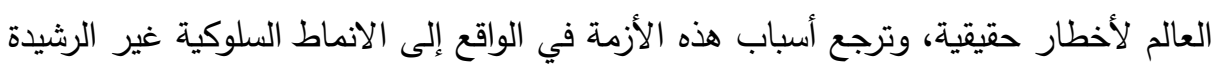
للأفراد نحو البيئة، فقضية تلوث البيئة هي قضية سلوكية في المقام الأول، وعليه فالإنسان يعتبر المصدر الأول للتلوث، ولمواجهة هذه المعضلة لا يكفي سن القوانين والتشريعات ما لم لم

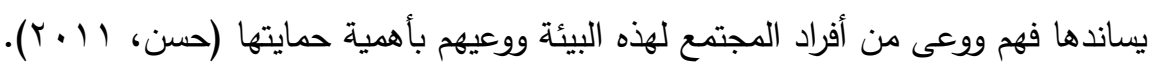

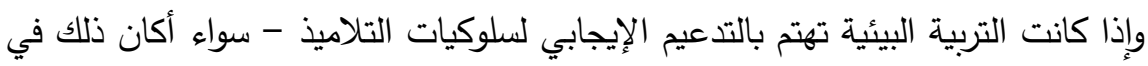
الأسرة أم في المدرسة - من خلال نقل مهاراتهم وزيادة معارفهم، فإنَّ تحقيق هذا الهدف يحتاج لتهاج

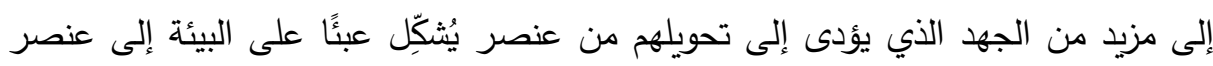

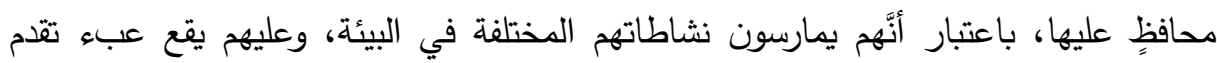

$$
\begin{aligned}
& \text { المجلد التاسع والأربعون، العدد السابع، الجزء السادس، يوليو . r. }
\end{aligned}
$$

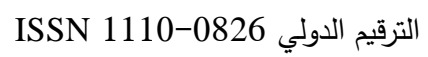


مجلة العلوم البيئية

معهد الدراسات والبحوث البيئية - جامعة عين شمس لبئه

احمد احمد عبد القدوس وآخرون

المجتمع. كما أنَّ درجة وعيهح واتجاهاتهم نحو البيئة يؤثر تأثيرًا بالغًا في استخدامهم لبيئتهم

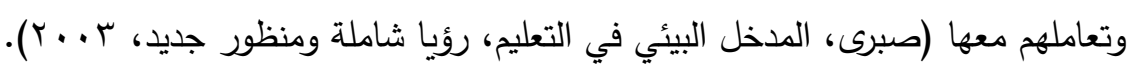
وتُشكل التربية البيئية إحدى الوسائل المهمة التي تكفل تحقيق أهداف حماية البيئة؛ فهي

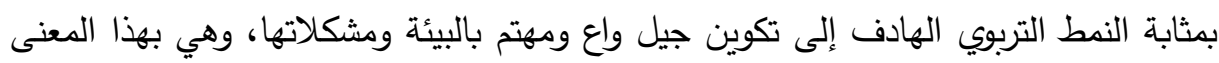
تقوم على تكوين القيم والسوكيات اللازمة لفهم العلاقات المعقدة التي تربط الإنسان بمحيطه بالئه البيوفيزيقي، وتوضيح حتمية المحافظة على مصادر البيئة، وهذا لن يتأتى إلامن خلال التتشئة

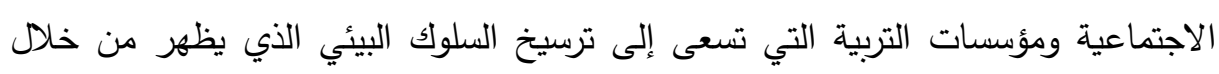

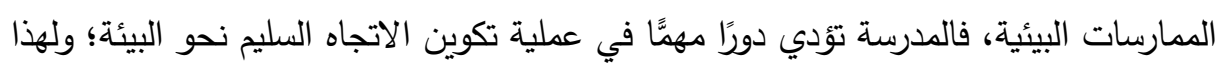

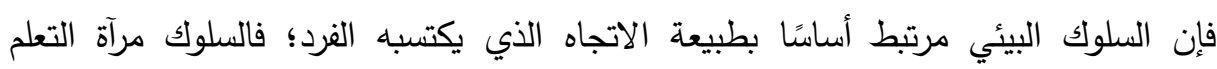

.(Scott \& Willits, 1994)

وتمثل الأنشطة الطلابية جانبًا مهمًّا من المجالات التي تحظى باهتمام كبير في التعليم؛ وذلك للدور الكبير الذي تلعبه في تكوين شخصية الطالب وتتميتها من مختلف جوانبها العقلية والنفسية والاجتماعية، حيث إن هذه الأنشطة تعمل على كسر الحواجز والعلاقات التقليدية، وذلك من خلال المواقف المتنوعة التي يثارك فيها الطالب من خلال هذه الأنثطة، والتي التئي تعمل بالتالي على تتمية مهاراته وقدراته ومقاومة المشكلات التي تواجهه.

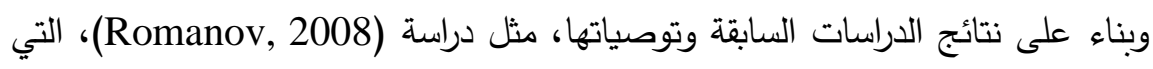

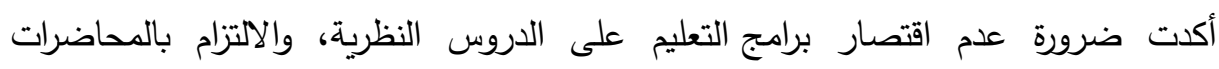

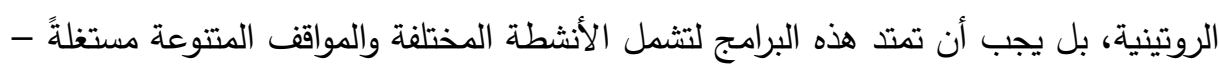

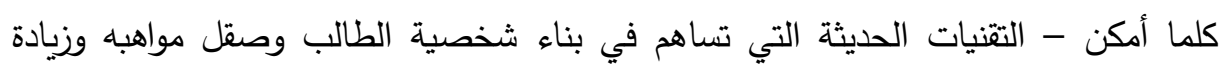

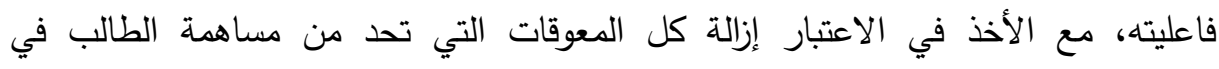
هذه الأنشطة بمختلف أنواعها؛ مما يساهم في تعديل السلوكيات غير الرشيدة نحو البيئة.

$$
\begin{aligned}
& \text { المجلد التاسع والأربعون، العدد السابع، الجزء السادس، يوليو • r. }
\end{aligned}
$$

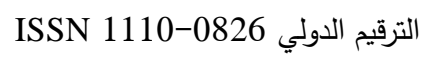


مجلة العلوم البيئية

معهد الدراسات والبحوث البيئية - جامعة عين شمس لبئه

احمد احمد عبد القدوس وآخرون

وبناءً على ذلك ركز البحث الحالي على تصويب بعض السلوكيات غير الرشيدة نحو البيئة من خلال تحديد قائمة من السلوكيات غير الرشيدة الأكثر شيوعا بين تلاميذ المرحلة الإعدادية؛ للوقوف على أساليب جديدة لممارسة التلاميذ للأنشطة في إطار تعديل السلوك غير الرشيد نحو البيئة.

\section{and In}

لاحظ الباحثون شيوع بعض السلوكيات غير الرشيدة نحو البيئة لدى تلاميذ المرحلة

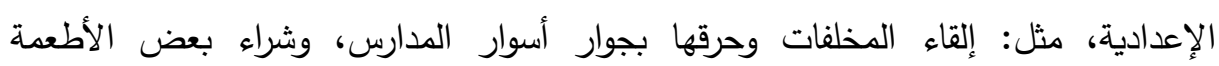
المكثوفة التي تكون عرضة للتلوث، وقطف الأزهار من الحدائق، والتعلق في الأشجار

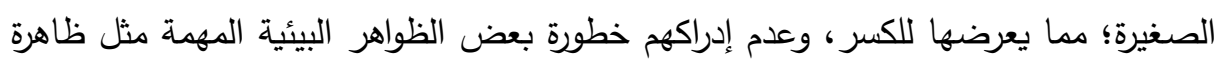
الاحتباس الحراري، وإلقاء المخلفات في المجاري المائية وفي نهر النيل.... إلخ. وللتثبت من هذه الملاحظة قاموا بإجراء مقابلات شخصية باستخدام أسئلة محددة مع الماري

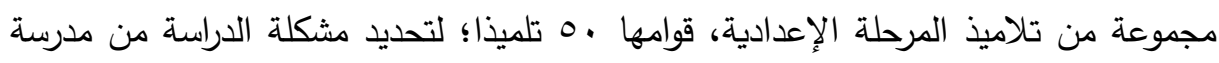

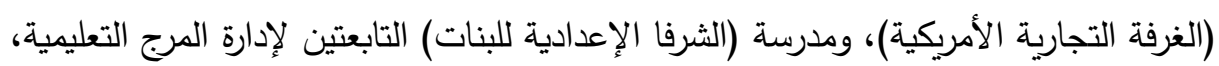

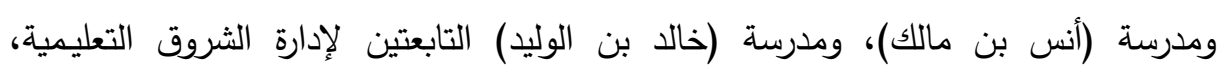
ومشرفي النشاط في هذه المدارس. وكانت الأسئلة وفق الجدول الآتي:

جدول (1):

\begin{tabular}{|c|c|c|c|}
\hline ע & نعم & السؤال & م \\
\hline$\leqslant 1$ & 9 & هل تشترك في الأنشطة البيئية في المدرسة؟ & 1 \\
\hline$r v$ & 14 & هل ترى أن الاشتراك فى الأنشطة البيئية شىء مفيد لك؟ & r \\
\hline 1. & $\leq 0$ & هل تؤثر المشكلات والقضايا البيئية فى المجتمع المحيط؟ & $r$ \\
\hline 10 & ro & هل هناك معوقات تمنعك من الاشتراك في الأنشطة البيئية؟ & $\varepsilon$ \\
\hline
\end{tabular}


مجلة العلوم البيئية

معهد الدراسات والبحوث البيئية - جامعة عين شمس لبئه

احمد احمد عبد القدوس وآخرون

وقد أسفرت الإجابات عن النتائج التالية: • نسبة rی ب تقريبا من تلاميذ المجموعة لا تشترك في الأنشطة البيئية في المدرسة. • ن نسبة • 1\% تقريبا من تلاميذ المجوعة تؤكد أن الاشتراك في النشاط البيئي مفيد.

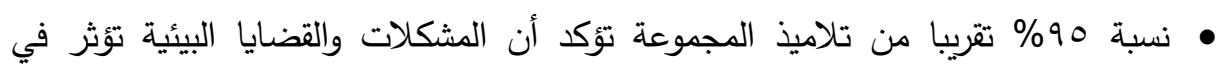
المجتمع المحيط. • نسبة 7 \% تقريبا من تلاميذ العينة ترى أن ثيَّة معوقات تمنعهم من الاشتراك في الأنثطة البيئية. كما أشار مشرفو النشاط بالمدارس ذاتها، وعددهم خمسة مشرفين، إلى: • ضعف الإمكانيات المادية والبشرية التي تساعد على إقامة الأنشطة. • • • •لة المحفزات التي تشجع التلاميذ على الاشتراك في النشاط البيئي.

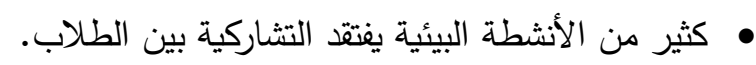

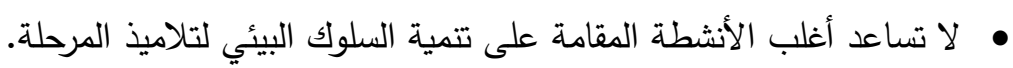

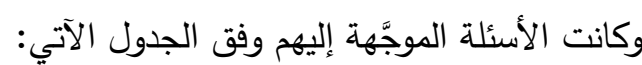

جدول (r):

\begin{tabular}{|c|c|c|c|}
\hline$\gamma$ & نعم & 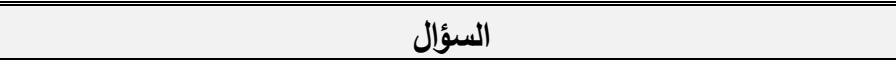 & م م \\
\hline$\varepsilon$ & 1 & هل الإمكانيات المادية والبشرية للمدرسة تساعد على إقامة الأنشطة البيئية؟ & 1 \\
\hline$r$ & $r$ & هل هناك محفزات لاشتراك التلاميذ في الأنشطة البيئية؟ & r \\
\hline$r$ & r & هل تيوكد وثيقة الأنثطة تتمية الاتجاهات الإيجابية نحو البيئية؟ & $r$ \\
\hline$\varepsilon$ & 1 & هل تقوم الأنشطة المنفذة على التشارك بين الطلاب؟ & $\varepsilon$ \\
\hline$\varepsilon$ & 1 & هل تساعد الأنشطة المنفذة على تتمية الوعى البيئي للطلاب؟ & 0 \\
\hline
\end{tabular}

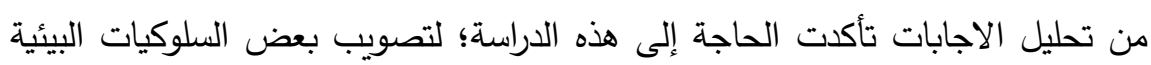
غير الرشيدة نحو البيئة لاى تلميذات المرحلة الإعدادية من خلال برنامج مقترح لأنشطة بيئية

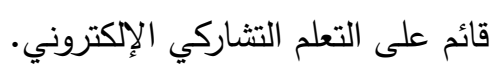

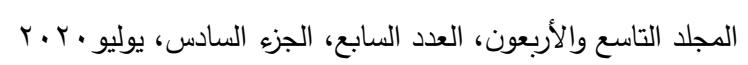

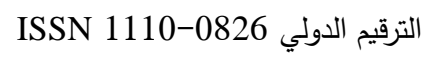


مجلة العلوم البيئية

معهد الدراسات والبحوث البيئية - جامعة عين شمس لبئة

احمد احمد عبد القدوس وآخرون

\section{أسريلا المهيث}

"ما فاعلية برنامج أنثطة بيئية مقترح قائم على التعلم التثاركي الإكتروني في تصويب بعض

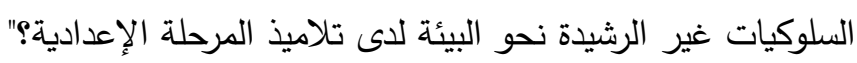
وتطلبت الإجابة عن السؤال السابق الإجابة عن الأسئلة الآتية:

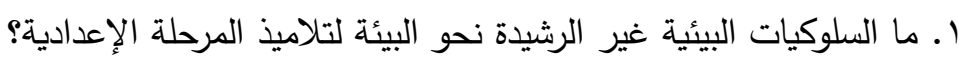

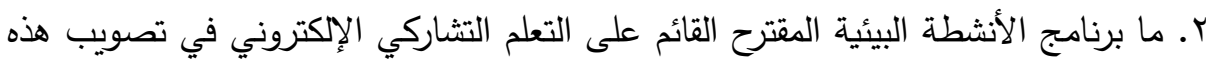
السلوكيات؟ r. ما فاعلية برنامج الأنشطة البيئية المقترح القائم على التعلم التشاركي الإكتروني في تصويب بعض السلوكيات غير الرشيدة نحو البيئة لاى تلاميذ المرحلة الإعدادية؟

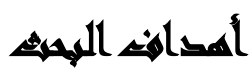

هدف البحث الى تصويب بعض السلوكيات البيئية غير الرشيدة تجاه البيئة من خلال: ا ـ تحديد قائمة للسلوكيات غير الرشيدة والاكثر شيوعا منها نحو البيئة لتلاميذ المرحلة

$$
\text { الاعدادية. }
$$

r. تحديد فاعلية برنامج أنشطة بيئية قائم على التعلم التشاركي الإكتروني في تعديل السلوك

$$
\text { غير الرشيد نحو البيئة. }
$$

\section{هرض الهمهي}

يوجد فرق دال إحصائياً بين متوسطى درجات تلاميذ المجموعه التجريبيه فى القياس القبلى / البعدى فى مقياس السلوك البيئى لصالح القياس البعدى.

$$
\begin{aligned}
& \text { المجلد التاسع والأربعون، العدد السابع، الجزء السادس، يوليو . F. }
\end{aligned}
$$

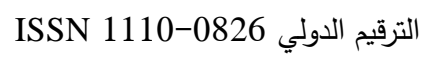


مجلة العلوم البيئية

معهد الدراسات والبحوث البيئية - جامعة عين شمس لبه آلبه

احمد احمد عبد القدوس وآخرون

\section{مشورت المهنه}

اقتصر البحث الحالي على الحدود التالية: • مجموعة من تلاميذ المرحلة الاعدادية التابعين لمدرسة الثرفاء الإعدادية بمحافظة القاهرة. • مجموعة من مشرفوا النشاط بمحافظة القاهرة.

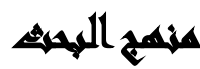

المنهج شبه التجريبي: يستخدم البحث المنهج شبة التجريبى ذو المجموعة الواحدة مع القياس القبلى والبعدى.

\section{أهميل البهمه}

$$
\text { قد يفيد البحث الحالي: - البح }
$$

ا. مخططى المناهج في وجود بديل للنظم التقليدية فى التعلم عبر التعلم الالكترونى

$$
\text { التشاركي. }
$$

r. مشرفي النثاط من خلال وجود بدائل تكنولوجية تساعدهم على التغلب على معوقات تتفيذ

$$
\text { النشاط البيئى. }
$$

r. يقدم مقياس سلوك بيئى لممارسات التلميذات نحو البيئية.

\section{كمطلحاهي (مهاهميم) المهيه}

التعلم الإكتروني التشاركي: نمط من التعلم القائم على التفاعل بين المتعلمين حيث أنهم يعملوا في مجموعات صغيرة يتشاركون في إنجاز المهمة أو تحقيق أهداف تعليمية مشتركة من الأن خلال أنثطة جماعية في جهد منسق باستخدام خدمات وأدوات الاتصال والتواصل المختلفة عبر الويب، ومن ثم فهو يركز على توليد المعرفة وليس استقبالها، وبالتالي يتحول التعليم من

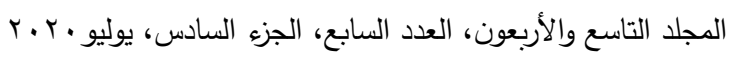

$$
\begin{aligned}
& \text { الترقيم الدولي 0826- ISSN 1110 }
\end{aligned}
$$


مجلة العلوم البيئية

معهد الدراسات والبحوث البيئية - جامعة عين شمس لبئه

احمد احمد عبد القدوس وآخرون

نظام ممركز حول المعلم يسيطر عليه إلى نظام ممركز حول المتعلم ويشارك فيه المعلم $\cdot(r \cdot 1 \cdot$ ، Edman)

الأنثطة: يعرف النشاط على أنه "نلك البرنامج الذي تتظمه المدرسة متكاملاً مع البرنامج

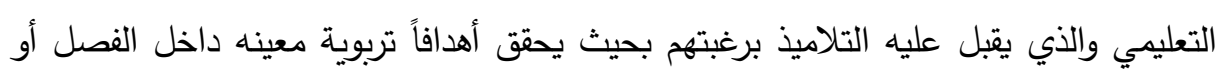

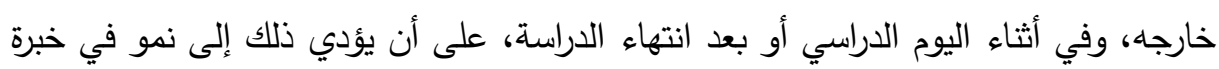
التلميذ وتتمية هواياته وقدراته في الاتجاهات التربوية والاجتماعية المرغوبة". السلوك البيئي: يرجع الأصل اللغوي لمصطلح" السلوك "إلى الفعل الثلاثي "سلك" (زيدان،

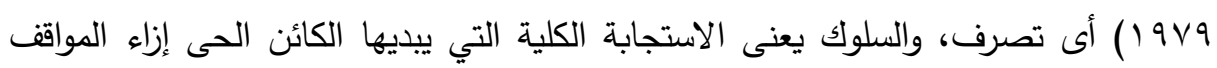

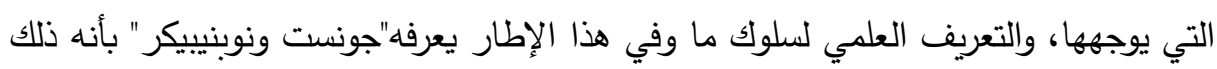
الجزء من تفاعل الكائن الحى مع بيئته، والذى يمكن من خلاله تحرى حركة الكائن في المكان

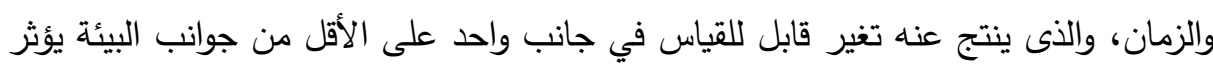

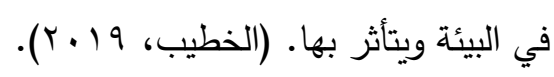

\section{السواساهي الساريهة}

بينت كثير من الدراسات العربية والأجنبية أهمية الأنثطة الطلابية، منها: دراسة (علوان،

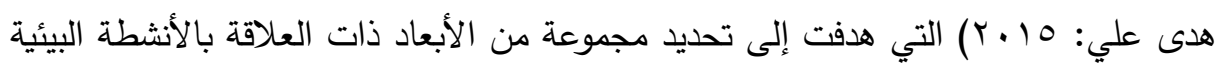

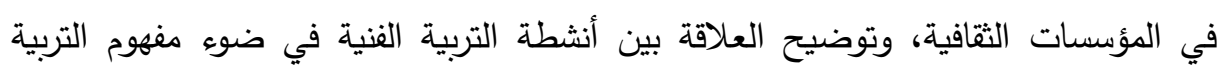
البيئية وبما يتتاسب مع فلسفة المؤسسات التعليمية. وتوصلت الدراسة إلى مجموعة من النتائج كان أهمها تطبيق الأنشطة الإكترونية الفنية في ضوه التربية البئية البيئية بالمؤسسات الثقافية لتعزيز الانتماء تجاه البيئة والمحافظة عليها.

كما بينت دراسة (الخراشي، ؟ . ب؟) أن الأنشطة الطلابية لها تأثير كبير في عملية إكساب المسؤلية الاجتماعية للطلاب وتتميتها كجانب أساسي في بناء شخصياتهر. 


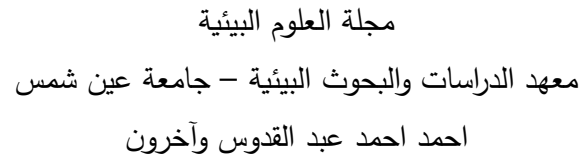

كما توصلت دراسة (Von Aufschnaiter, 2007) إلى وجود علاقة مطردة بين الأنشطة الطلابية وتتمية التفكير والتعليم للطلاب وذلك أثثاء المشاركة في الأنشطة، خاصة التي تتم في مختبرات العلوم (الفيزياء، والكمياء).

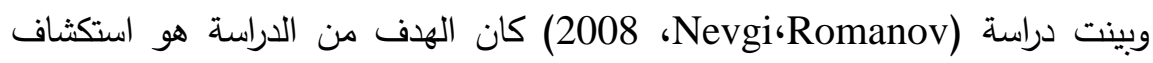
العلاقة بين درجة المشاركة ونتائج التعلم في دورة التعلم الإكتروني على المعلوماتية الطبية. تمت دراسة النشاط العام في استخدام مواد الدورة ودرجة المشاركة في منتديات المناقثة لدورة

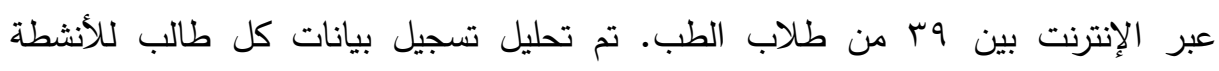

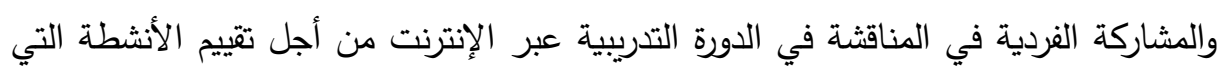
تتبأت بنتيجة التعلم. ارتبطت درجات الدوة العليا بدراسة مادة الدورة بثكل متكرر وأيضًا

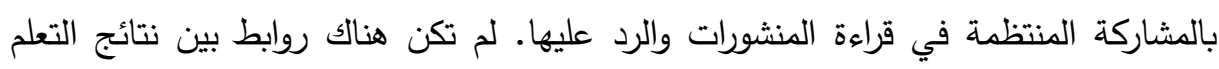

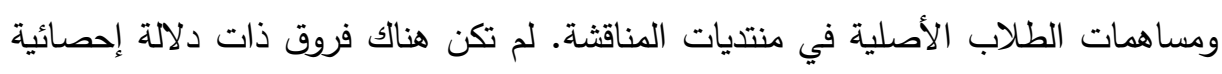
بين الطلاب والطالبات في كيفية استخدامهم لمختلف مكونات مادة التعلم. وقامت دراسة (سلامة، ـ99 1) على بناء برنامج مقترح في التربية البيئية للاطفال

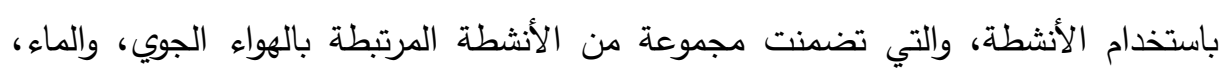

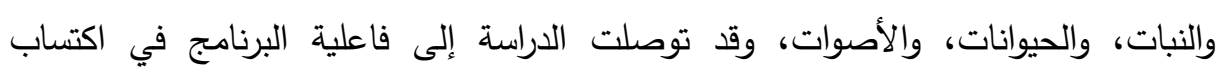
الأطفال عينة البحث السلوكيات البيئية المستهدفة. والتان. وتوصلت الدراسة إلى مجموعة من النتائج من أهمها النظر على النواحى الاجتماعية عند الندائل

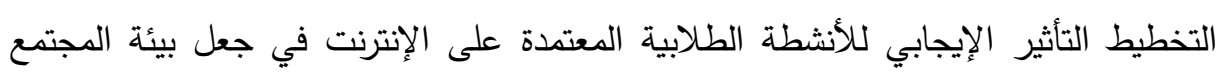

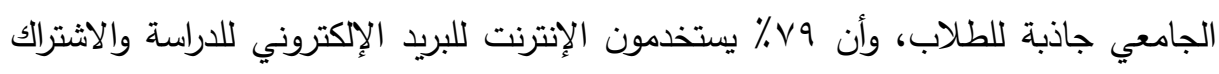

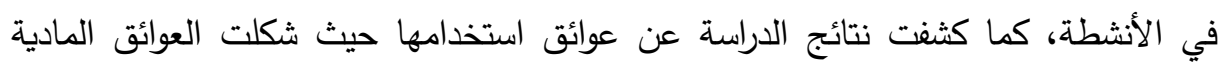
المرتبة الأولى، ثم الأمية المعلوماتية، والسلبيات التي يحدثها الإنترنت في المجتمع تأتي عائقا

$$
\begin{aligned}
& \text { المجلد التاسع والأربعون، العدد السابع، الجزء السادس، يوليو • r. }
\end{aligned}
$$

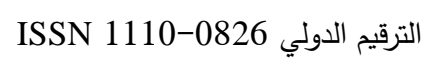




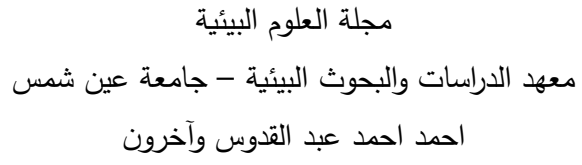

ثالثا. كما يرى مجتمع الدراسة ضرورة وجود شبكة إنترنت خاصة بالأنشطة الطلابية وربطها مع باقي الكليات لتشجيع أعضاء هيئة التدريس والطلبة لممارسة الأنشطة.

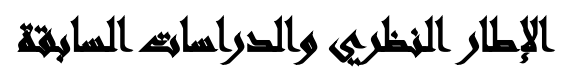

المحور الأول: الانثطة البيئية الإكترونية التشاركية: تمثل الأنثطه البيئية التشاركية واحدة

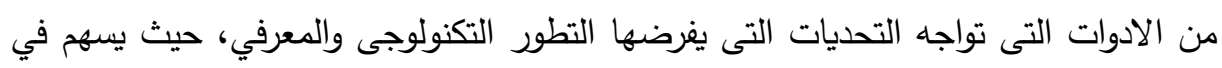
تلبية احتياجات التلاميذ، وتحقيق التواصل الفعال، واتاحة الفرص التعليمية لاكبر عدد ممكن

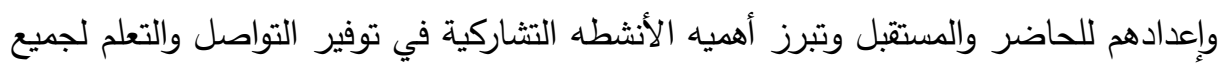

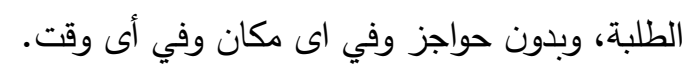

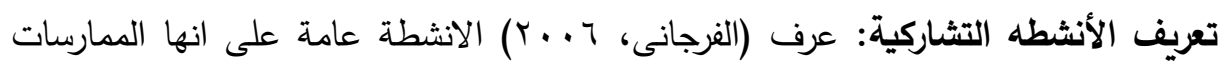
التعليمية - التعلمية التى يؤديها المتعلمون بالتعاون مع المعلم داخل البيئه المدرسية وخارجها كجزء من عملية التعليم والتعلم المقصودة بهدف بناء وأثراء الخبرة في المجالات المعرفيه

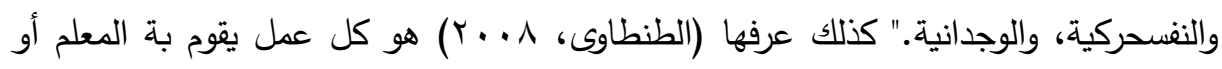
المتعلمون أو كلاهما معا لغرض تحقيق أهداف معينه سواء تم هذا العمل داخل حجرة الدراسة أو خارجها. ويمكن تعريف الأنشطه التشاركية اللاكترونية عامة بأنها خطوات علمية منطقية تتبع

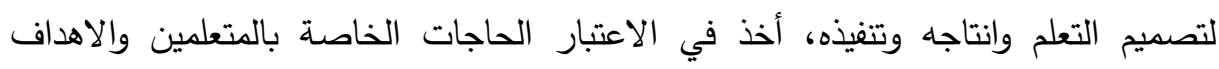

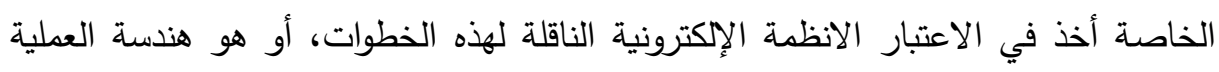

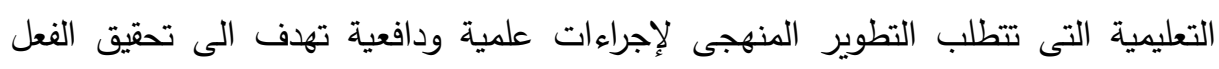
التعليمى في فضاء مكانى وزمانى، وهويعتبرجسرا يصل بينالعلوم السلوكية والمعرفيه،

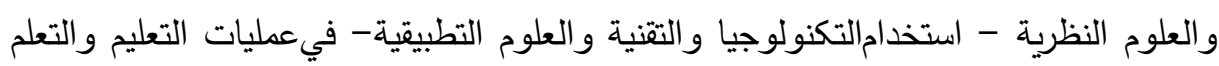


مجلة العلوم البيئية

معهد الدراسات والبحوث البيئية - جامعة عين شمس لبئه

احمد احمد عبد القدوس وآخرون

أهمية الانثطة البيئية الإكترونية: تكمن أهمية الانشطة البيئية الإكترونية عندما تأخذ موقعا

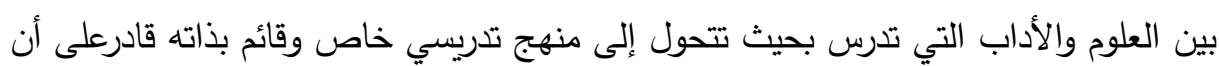

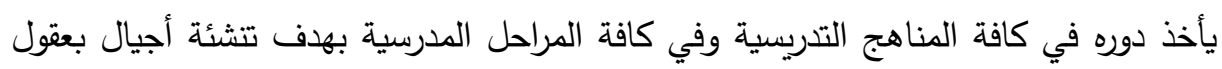
جديدة تعي مفهوم الأنشطة، وتعمل على تطبيقها؛ وعليه فمن خلال الأنشطة يمكن إحداث تغييرات جذرية في طرق التنكير والسلوك البيئي لدى التلاميذ بحيث يتصرف كل ولئه تلميذ وكأنه

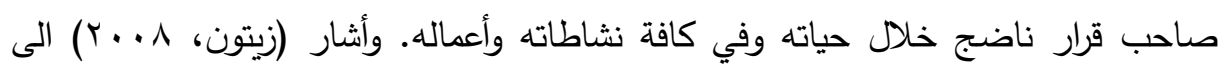

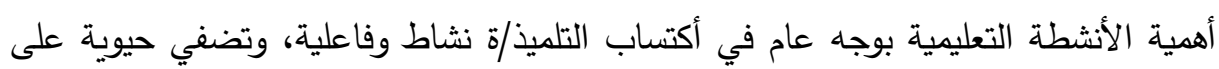
عمل المعلم داخل الفصل، كما تساعد على ربط الخبرات السابقة للتلاميذ مع الخبرات الجديدة

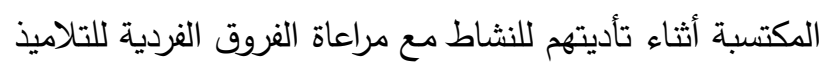
واستخدام الانشطة البيئية الإلكترونية تعمل على توفير إمكانية تعزيز عملية التعلم عن طريق الوصول الى حقائق تعليمية يصعب الوصول اليها من الواقع مما يؤدى إلى زيادة تحسين النتائج التعليمية، حيث يمكن للتلميذ الوصول إلى المحتوى دون قيود الزمان والمكان مما يسهل عملية التعلم كما أن استخدام الانشطة البيئية الإلكترونية تعمل على التحسين لهني المستمر للبيئه المحيطة حيث يمكن للتلميذ من القيام بدور تثاركى بين أقرانه في تبادل

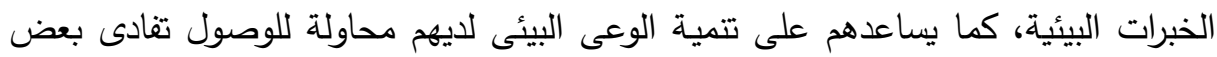

دور مشرف النشاط في تقويم الانشطة البيئية: والمقصود بذلك هو تحديد المهارات والسلوكيات البيئية المراد معرفتها، فقد يسعى المعلم للتعرف على درجة إتقان التلميذ/ة لمهارة بيئية معينه مثل مهارة اعادة تدوير الورق، وقد يرى أهمية قدرته على استخدام المفاهيم

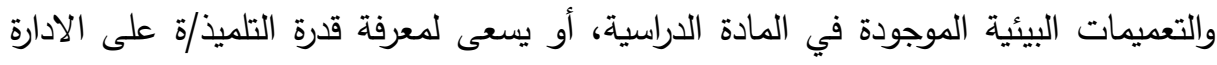
البيئية داخل الفصل والتعامل مع ذملائه، (اللقانى، ب . . ب).

$$
\begin{aligned}
& \text { المجلد التاسع والأربعون، العدد السابع، الجزء الساد، يوليو • r. }
\end{aligned}
$$

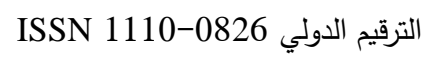


مجلة العلوم البيئية

معهد الدراسات والبحوث البيئية - جامعة عين شمس لهـ آلبه

احمد احمد عبد القدوس وآخرون

المحور الثانى التعلم التشاركى الاكترونى: أدى التطور الحادث في تكنولوجيا المعلومات ونظم الثبكات والاتصالات وظهور الجيل الثاني من الانترنت (Web2.0) وانتشار شبكات

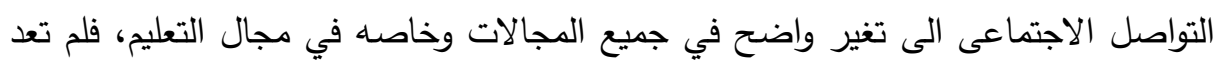

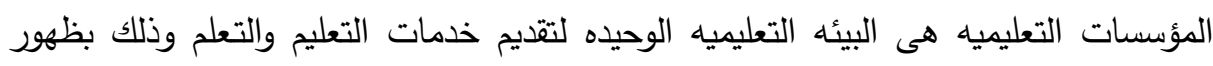
مصطلح التعليم الاككترونى (E_Learning) بدرجه كبيره في خدمات التعلم ويعد التعلم الإكترونى من أهم تطبيقات تكنولوجيا الاتصالات في مجال التعليم وتطور هذا المفهوم ليظهر

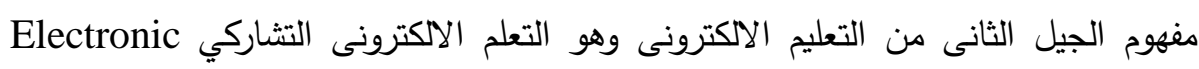
Collaborative Learning. يعتبر التشارك من أهم عمليات التفاعل الاجتماعى كما انه من الأهداف الرئيسية للتربية

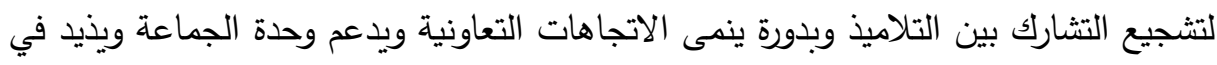

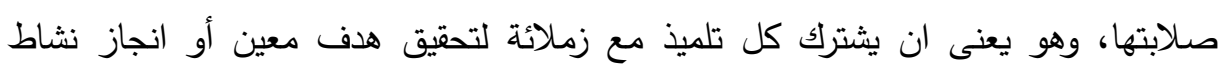

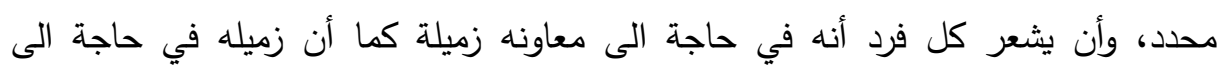
معاونته، ومن هنا فأن التثارك ظاهرة ايجابية تعتمد عليها كثير من الانثطة التربوية. وفي فئ فئه

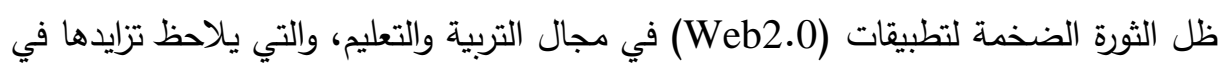
الآونه الأخيرة - يوماً بعد يوم- فقد ظهرت صور عديدة وجديدة لهذا التطور، منها: استخدام الحاسب الآلي بوصفه أداة مساندة للمعلم، ثم توظيفه كوسيط في إنجاز الأهداف التعليمية، ثم

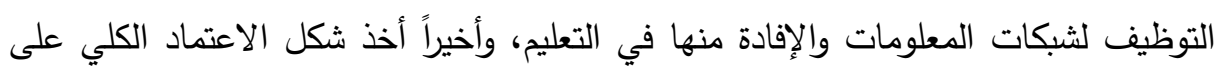

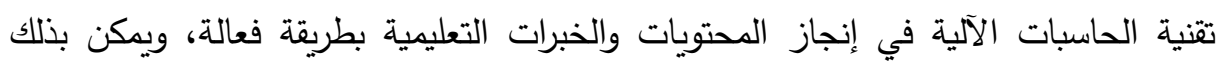

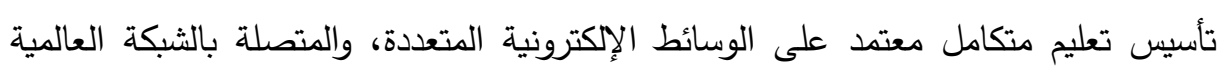

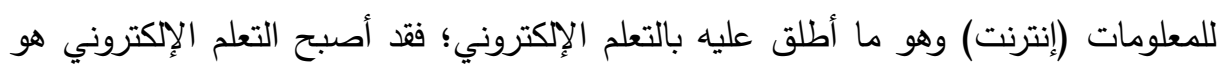
ذللك النوع الذي يوظف الوسائط الإكترونية في تحقيق الاتصال بين المعلم والمتعلمين، والمعلم

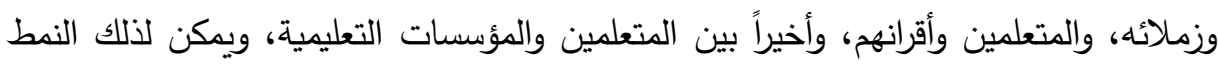
266

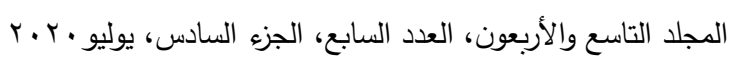

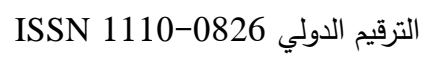




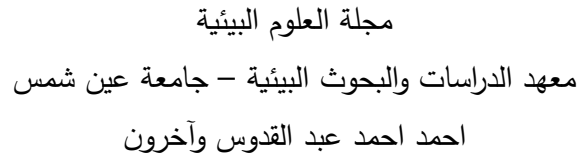

من التعلم ألا يحتاج إلى مبان مدرسية أو صفوف دراسية، بل يمكن إلغاء جميع المكونات المادية للتعليم، ويتم التفاعل بين المعلم والمتعلم عن طريق الاتصال والتواصل عبر هذأه الوسائط وتقديم الخبرات والأنشطه إلكترونياً، والاطلاع على المكتبات الإلكترونية، وتصفح لإنح

$$
\text { الكتب الإلكترونية. }
$$

\section{الأسس النظرية للتعلم التشاركي:}

• النمو الاجتماعى لـ فيجوتسكى Social Development Theory (النظرية البنائية):

يتجذر التعلم التشاركي من النظرية التعاونية في مفهوم لفيجوتسكي من التعلم يسىى التئى

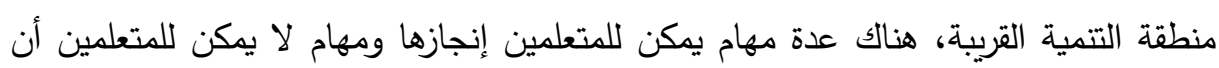

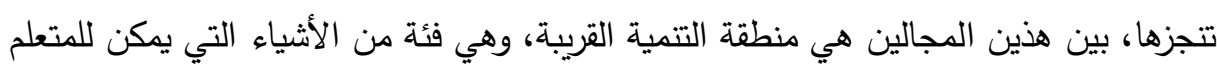
أن يتعلم فيها ولكن بمساعدة التوجيه، وفي منطقة التتمية القرببة يعطي التوجيه للمتعلم بثأن

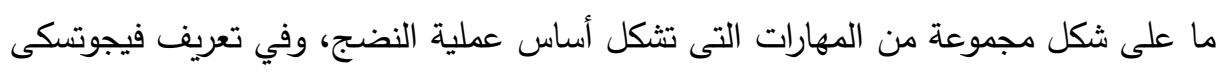

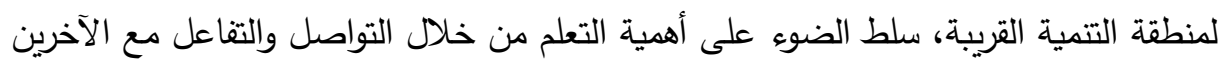
بدلا من مجرد العمل المستقل، وقد أتاح هذا الطريق لأفكار التعلم الجماعي، واحدة منها التعلم

• نظرية المرونه المعرفيه:Flexibility Cognitive Theory: تؤكد هذه النظرية على النى الاتى: أن الأساليب التقليدية التى تعتمد على التلقين: والحفظ والاسترجاع لا تسمح

$$
\text { باكتساب مستويات عليا من المعرفة. }
$$

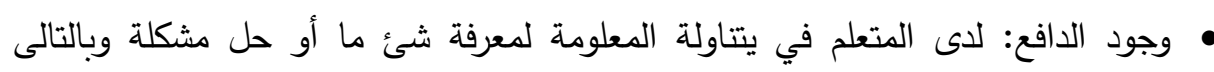

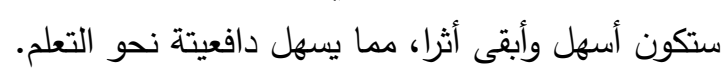

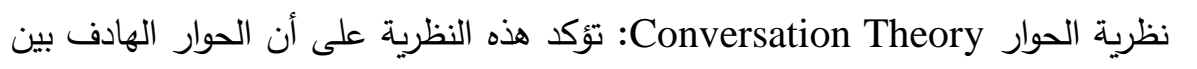

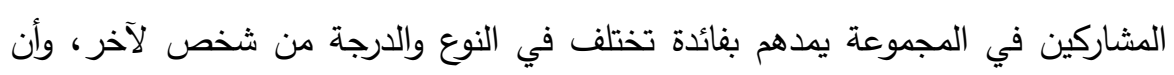

$$
\begin{aligned}
& \text { المجلد التاسع والأربعون، العدد السابع، الجزء السادس، يوليو • r. }
\end{aligned}
$$

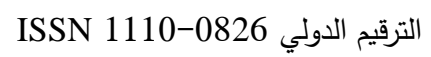




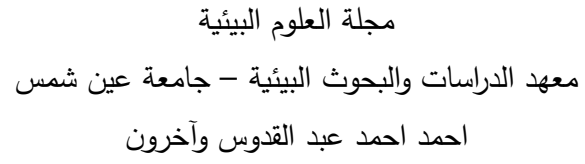

هذا الحوار يمر بثلاث مستويات تبدأ بمناقثة عامة، ثم مناقشة الموضوع، ثم التحدث عن التعلم الذى تم حدوثه.

ماهية التعلم التشاركي الإكترونى: مع تطور شبكة الإنترنت وانتشار خدمة الوصول للإنترنت

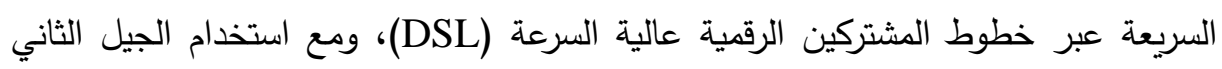
من الانترنت (Web2.0)، والذي يندرج تحت مظلته البرامج الاجتماعية مثل المدونات

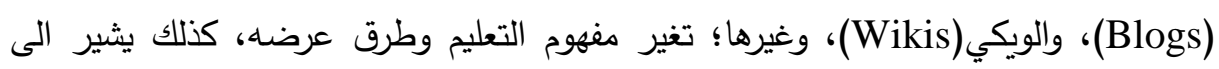

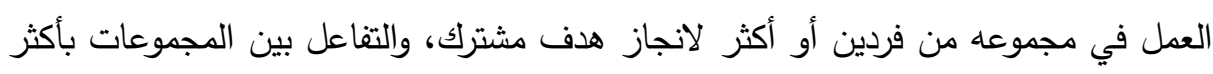

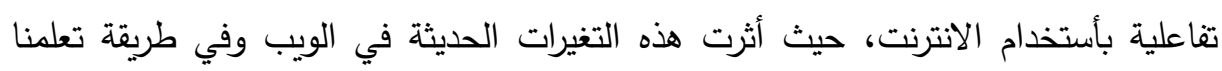
وتعاملنا مع من حولنا.

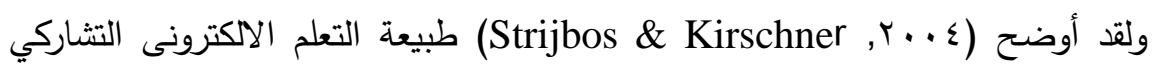

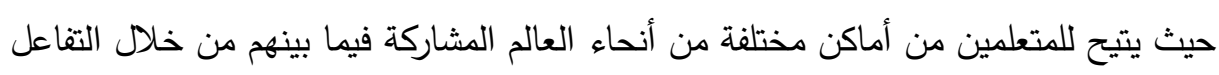
الإجتماعى المصاحب لهذا النوع من التعلم، وهذا يتطلب من المعلمين إثارة دافعية المتعلمين

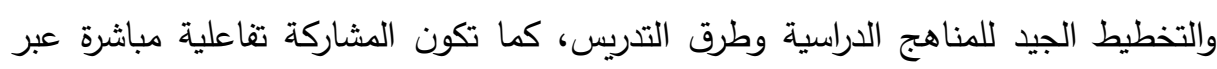

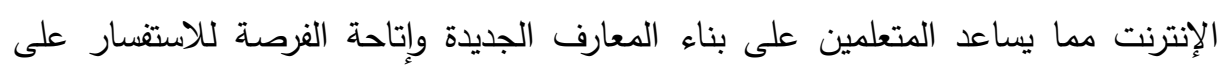
أسئلتهم والتعلم من بعضهم البعض بإتاحة ماتعلمه المتعلمون تشاركيا.

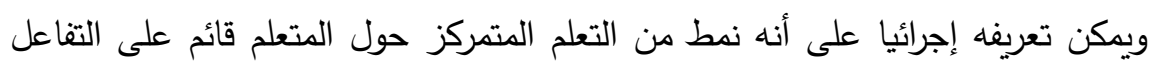

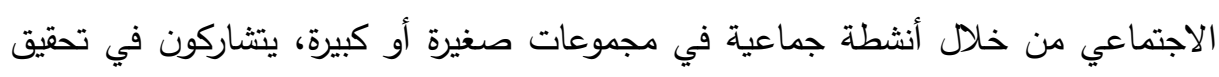

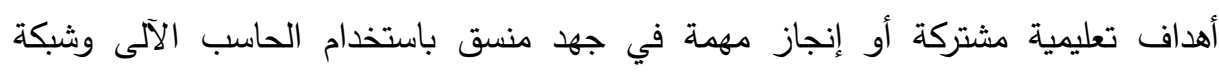
الإنترنت(Web2)، سواء في لقاءت متزامنه أو غير متزامنه ويتثاركون لبناء معرفة جديدة لتحقيق هدف مشترك. 


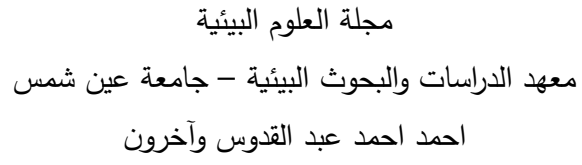

استراتيجيات التعلم التشاركي: استراتيجية التعلم من خلال الاتصال بين الأشخاص: تقوم هذه

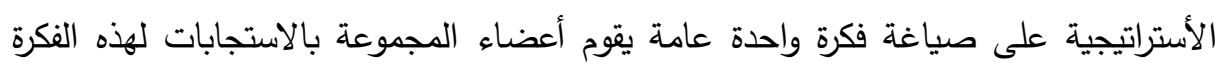
بالاعتماد على قدراتهم المعرفيه. استراتيجية المنتج التشاركي Collaborative production: العنصر الأساسي في هذه الاستراتيجية هو القدرة علي تتظيم الأنشطة التعليمية التي تعتمد على المناقثة بين أعضاء

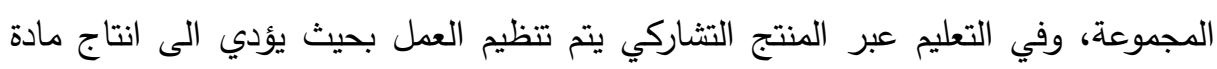
مشتركة. طريقة فكر - زاوج - شارك Think - Pair - Share: عمل هذه الطريقة علي تقسيم المتعلمين الي أزواج، ويقوم متعلمان بالتفكير معا للوصول الي حل المشكلات ثم كتابة الحل،

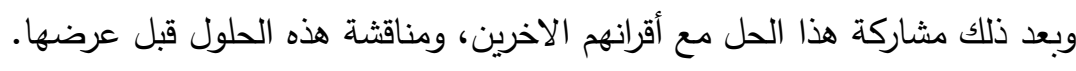
أدوات التعلم التشاركي الاكتروني: - أدوات تساهم في بناء المحتوى التعليمى: مثل مواقع التواصل الاجتماعى ومواقع التدوين

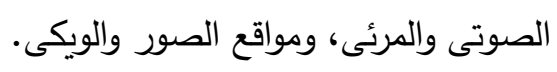
- أدوات تساعد في التواصل: وتأتى مكملة لوظيفة البريد الإلكترونى مثل خدمة. (Twitter)

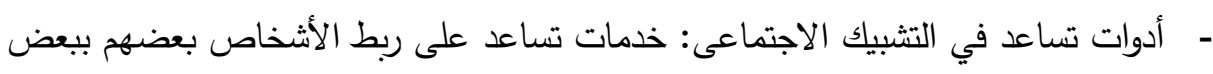

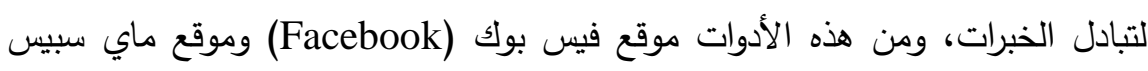

(MySpace). - أدوات تساعد على فاعلية الأدوات السابقة: مثل استخدام خلاصات المواقع واستخدام الوسم لتوصيف المصادر المختلفة.

$$
\begin{aligned}
& \text { المجلد التاسع والأربعون، العدد السابع، الجزء السادس، يوليو • r. }
\end{aligned}
$$

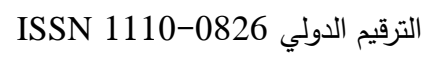




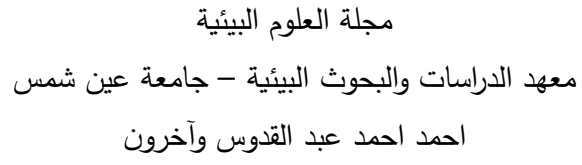

المحور الثالث السلوك البيئى: قضية المحافظة على البيئه وحمايتها وصيانتها واستغلالها

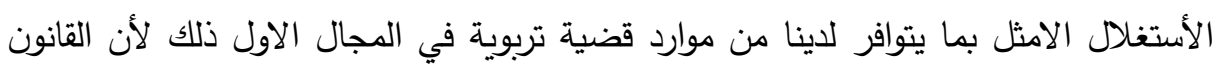

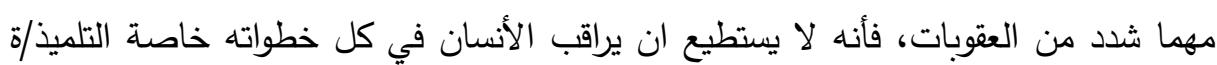
وهو داخل مسكنه او في الطريق العام او في المدرسة. وهناك الكثر من السلوكيات التى تصدر من الانسانتجاة البيئه تعمل على الاسراف في استهلاك الثروة البيئية، ولذلك تتضب او تتتاقص او تتلاشى وينطبق ذلك على مصادر المياة

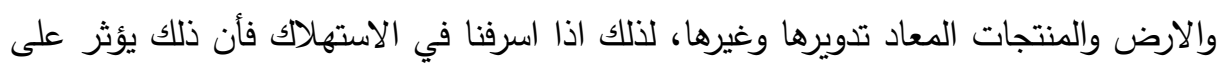
مستقبل المصادر مما يضر بنا وبالمجتمع وبالاجيال القادمة. وتكثف الدراسات عن وجود نقص في معارف التلاميذ حول البيئه، وتعمل برامج وانثطة التربية البيئية داخل الددارس على تتمية الوعى البيئى وفي تغيير سلوكة نحو الافضل، ولكن فئن

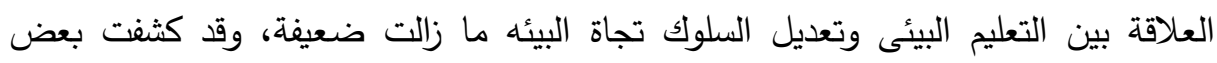

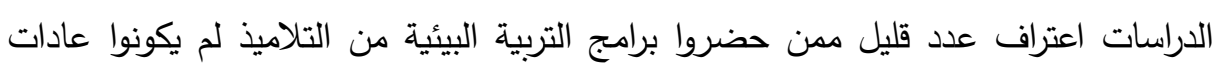

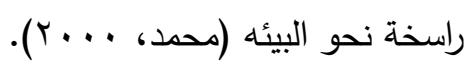

الأصل اللغوى لمصطلح سلوك "Behavior" إلى الفعل "سلك" أى تصرف ويعنى

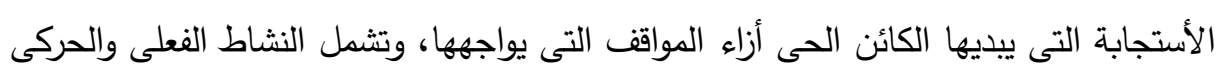
والانفعالى التى يمكن ملاحظتها أو التغييرات الجسمية التى يمكن قياسها، والتى يقوم بهاء الفرد

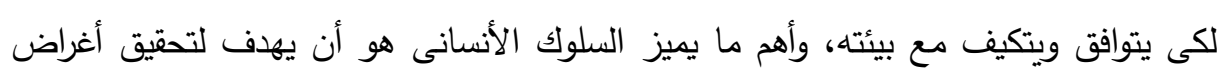

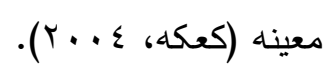

اما السلوك البيئى فقد عرفه معجم البيئة والتلوث قاموس البيئه العامه (ع ـ. با) بأنه

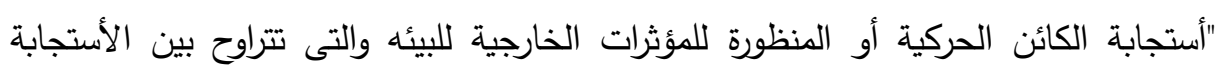

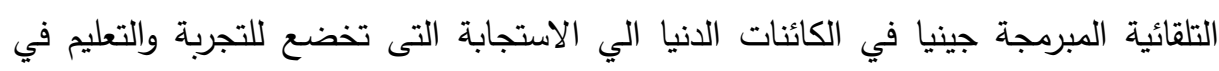
الحيوانات الدنيا" (كعكه، ع . . ب).

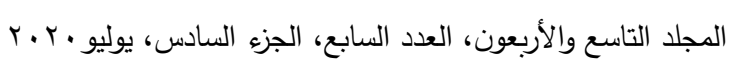

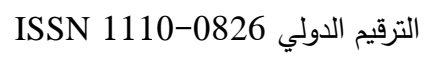




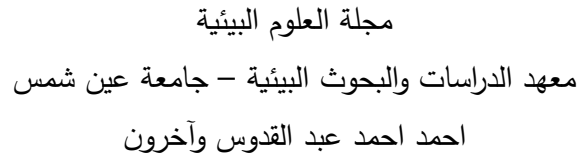

ويقصد بالسلوك البيئى في هذا البحث " النشاط أو الفعل الذى يقوم به التلميذات مع أقرانهن ويكون الهدف منه المحافظة على البيئه، ويتم أكتساب هذا السلوك من خلال الانشطة البيئية التشاركية من خلال الانترنت. النظريات المرتبطة بتعديل السلوك البيئى: - نظرية الأنتشار الإجتماعى The Theory of Social Diffusion : يحدث الانتشار السلوكى عندما يقوم فرد أو مجموعة بتطوير السلوك أو ابتكار فكرة أو سلوك جديد، وهو الأنساع وسيلة للتأثير العام للسلوك على من حولة من الاقارب والأصدقاء أكثر من استيعابة

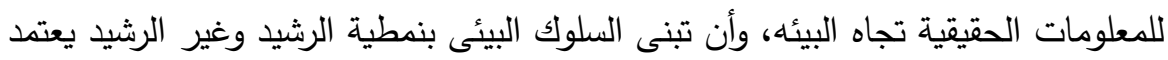
وفق هذه النظرية على خمس خطوات. - نظرية الميدان(الواقع) Field Theory: وهى ان السلوك يساوى دالة في كل من الفرد والبيئه ويمكن التعبير عن تلك النظرية بالمعادلة (B) = f(P+E) وتحدد هذه النظرية السلوك على أنه تغيير يحدث خلال فترة حياه الفرد، بمعنى أن السلوك هو أى تغيير في العوامل النفسية والبيئية ويحدث عن طريق فعل الفرد، وتتكون العوامل الخاصة بالبيئه في لئي هذه النظرية من زمن السلوك ومكان السلوك وتثاعل الفرد مع أناس آخرين كما أن هذه ولنه

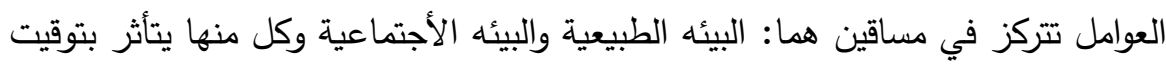
السلوك، حيث تثمل البيئه الطبيعية الابعاد المادية للسلوك والوقت والمكان. - نظرية الفعل المسبب Theory of Reasoned Action: وتقوم هذه النظرية على النى أفتراض أن الفرد لديه المنطق في الاستخدام المنظم لما هو متاح له من معلومات، وهذا

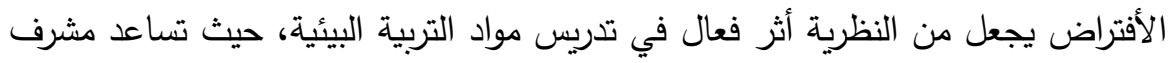
النشاط البيئى من اتخاذ القرارات المنطقية اللازمة، وتركز مسلمات هذه النظرية على لئى

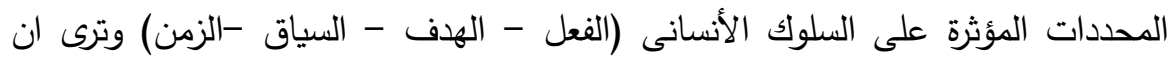
هناك ما يسمى بالمغزى السلوكى وهو ما يسبق السلوك وهو الذى يقودة ويدفعه.

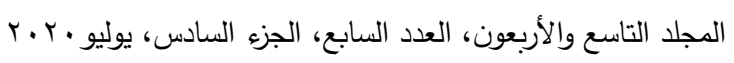

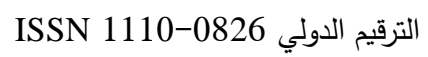




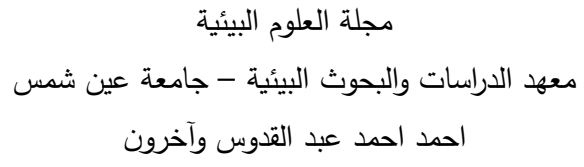

- - نظرية سكنر Skinner Theory: تقوم النظرية على دراسة السلوك الأنسانى والعلاقة بين

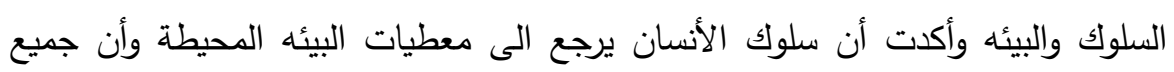

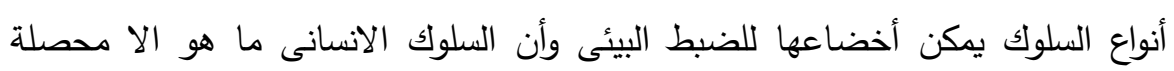
لتفاعل الانسان مع بيئته ونتاج هذا السلوك هو الذئ يحدد مصير هذاع السلوك مستقبلاً

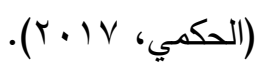

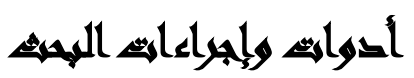

أولاً: اعداد قائمة بالسلوكيات غير الرشيدة نحو البيئة وتحديد الأكثر شيوعا لاى تلميذات

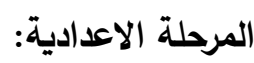

1 ـ مراجعة نتائج دراسات سابقه تتاولت السلوكيات والمشكلات البيئية. r. مراجعة الأدب التربوى في مجال السلوكيات والمشكلات البيئية. r. استطلاع رآى مجموعة من أولياء الامور ومعلمى المرحلة الاعدادية عن السلوكيات البيئية غير الرشيدة لدى التلميذات. ع. فى ضوء الخطوات السابقة تم اعداد قائمه بالسلوكيات البيئية غير الرشيدة لدى تلاميذ

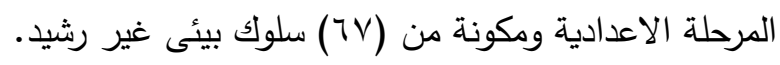

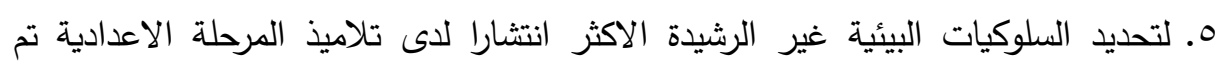

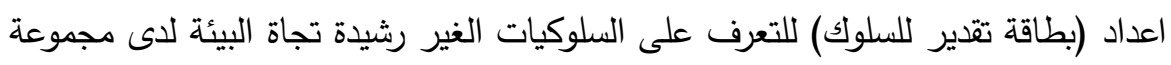
من التلاميذ بمدرسة الثرفاء الاعدادية للبنات بمحافظة القاهرة بواسطة معلمى العلوم

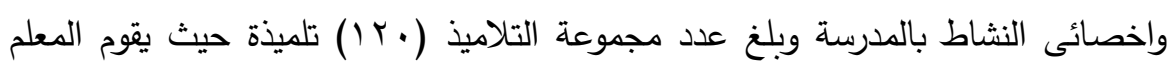
بتسجيل مدى تكرار السلوك لاى التلميذات. 
مجلة العلوم البيئية

معهد الدراسات والبحوث البيئية - جامعة عين شمس لبه

احمد احمد عبد القدوس وآخرون

جدول(ب): الصورة العامة لمستوى ممارسة السلوكيات البيئية غير الرشيدة لتلميذات مجموعة

\begin{tabular}{|c|c|c|c|c|c|}
\hline & & & \multicolumn{3}{|c|}{ البحث } \\
\hline النسبة المئوية للتكرار & التكرار & الارجة المقابلة لكل & النسبة المئوية & المستوى & s \\
\hline- & - & • ا Y درجة فأكثر & ف فأكثر \% Vo & مرتفع & 1 \\
\hline$\%$ \% & ra & •ــا الى • الب درجة & \% \%० إلى \%०. & متوسط & $r$ \\
\hline$\% \uparrow \wedge, r$ & Ar & أقل من • ء ا درجة & أقل من . 0\% & منخفض & $r$ \\
\hline
\end{tabular}

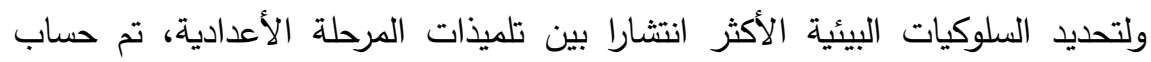

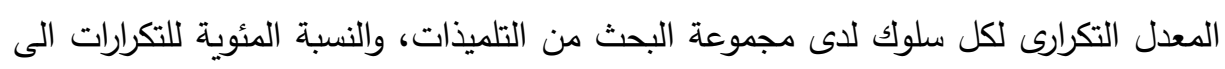

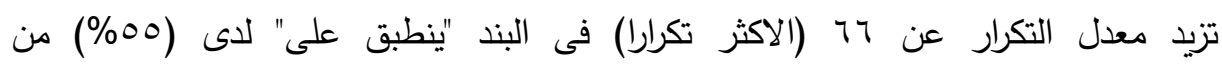

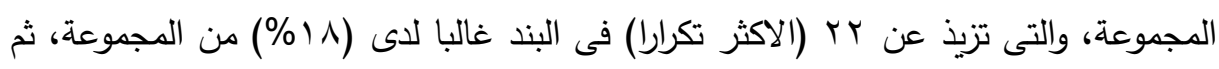

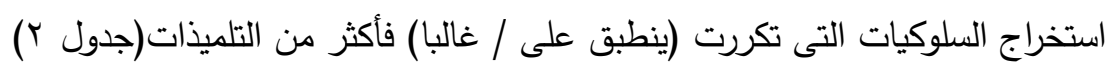
جدول (؛): السلوكيات البيئية الأكثر انتشارا بين تلميذات المرحلة الاعدادية الئية

\begin{tabular}{|c|c|c|c|}
\hline \multicolumn{2}{|c|}{ مدى ممارسة التلميذات } & \multirow{3}{*}{ الجملة المعبرة عن السلوك } & \multirow{3}{*}{ s } \\
\hline غالبا & ينطبق على & & \\
\hline ك & 5 & & \\
\hline ro & ir & مشاركة زملائي في تتظيف فناء المدرسة & 1 \\
\hline ro & $7 r$ & يرتبط تلوث البيئه بالغازات المنبعثة من محركات السيارات & r \\
\hline$r \varepsilon$ & rt & اختار الطعام الطازج مثل الفواكه والخضروات & r \\
\hline rt & 00 & استخدم المواد الكميائية في تتظيف المنزل & $\varepsilon$ \\
\hline rt & 70 & أغلق الباب او الثباك عند استخدام المدفأة او التكييف عند التشغيل & 0 \\
\hline $1 \cdot$ & $\mathrm{V} \cdot$ & ينبغى ذيادة المبيدات الحشرية في المنزل للقضاء على الحشرات & 7 \\
\hline $1 \cdot$ & $\wedge \wedge$ & استمتع بقطف الازهار وأهدائها & $\mathrm{V}$ \\
\hline rt & r. & يزعجنى منظر المخلفات في الشوارع العامة & $\Lambda$ \\
\hline ro & 07 & انشاء الحدائق المنزلية أمر غير ضرورى & 9 \\
\hline M & VY & اشجع السائقين على استخدام منبة الصوت (الكلاكس) متى شاء & 1. \\
\hline
\end{tabular}

المجلد التاسع والأربعون، العدد السابع، الجزء السادس، يوليو ·.r.

273

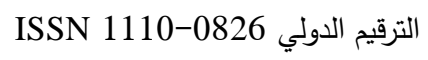


مجلة العلوم البيئية

معهد الدراسات والبحوث البيئية - جامعة عين شمس لبه

احمد احمد عبد القدوس وآخرون

\begin{tabular}{|c|c|c|c|}
\hline$\varepsilon$. & 77 & أحاول شراء الملابس المستعملة ولعب الاطفال والكتب بدلا من الجديد & 11 \\
\hline rt & $\varepsilon r$ & اشجع على قطع الاشجار اذا كان مبرراً & it \\
\hline ro & $\varepsilon \varepsilon$ & عائلتي تستخدم المصابيح الكهربائية والأجهزة الموفرة للطاقة & ir \\
\hline 1. & $\Lambda$. & القى القمامة في الطريق العام & $1 \leqslant$ \\
\hline$r \cdot$ & $r$. & ارفع صوتى بشكل مزعج عندما العب وحدى & 10 \\
\hline זr & \& & اترك ما تبقى من طعام مكشوف بعد الاكل & 17 \\
\hline «o & $0 \leqslant$ & اسرف في الماء عند استخدام اليدين او الوجة او الاسنان & iv \\
\hline "r & $\varepsilon$. & ارفع صوت التليفزيون بشكل عالى اثثاء المشاهده & 11 \\
\hline ro & $\varepsilon \varepsilon$ & أشارك زملائي في المدرسة بكتابة بعض الذكريات على الجدران & 19 \\
\hline rY & 7. & افضل اطفاء المصابيح الكهربائية عند خروجى من المكان & r. \\
\hline rr & $\wedge$. & اترك شاحن الموبايل طوال اليوم في الفيشة الكهربائية & Y) \\
\hline$r$. & 7. & اتتاول الخبز الغير مغطى ومعرض لملوثات الهواء & rr \\
\hline rY & 77 & القى مخلفات الطعام في الثارع او فناء المدرسة & r \\
\hline זr & $\varepsilon$. & اتتاول الخضراوات والفاكهة المعروضة بدون غسيل & $r \varepsilon$ \\
\hline ro & 77 & انام في الحجرات الغير متجدد فيها الهواء & ro \\
\hline ro & 77 & استعمال سماعات الأذن وسماع الأغاني بصوت عالِ & ry \\
\hline ro & ro & اهمال غسيل الاسنان & TV \\
\hline ro & rr & وجود بقايا الطعام في أماكن المعيشة & rᄉ \\
\hline$r \cdot$ & 77 & تربية الدواجن وحيوانات في نفس مكان المعيشة & rq \\
\hline$r$. & 77 & اللعب بالعاب معاد استخدامها من المخلفات & r. \\
\hline
\end{tabular}

ومن الجدولين السابقين (r) و(ع) تبين للباحث أن معظم السلوكيات البيئية الغير رشيدة

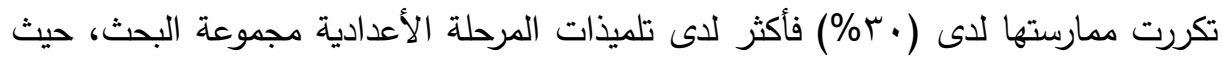

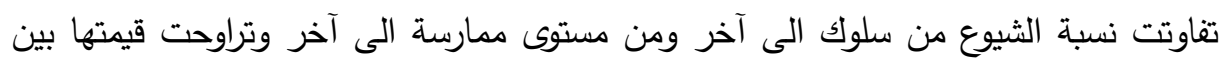

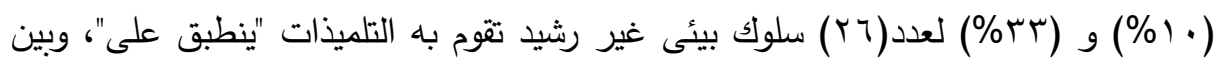

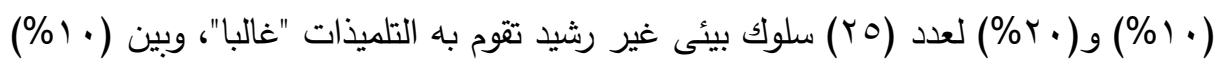

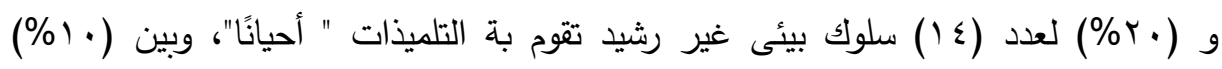


مجلة العلوم البيئية

معهة الدراسات والبحوث البيئية - جامعة عين شمس البه

احمد احمد عبد القدوس وآخرون

و(ء ا\%) لعدد (• (1) سلوك بيئى غير رشيد تقوم بة التلميذات " نادرا "، "، وبين (• (1\%)

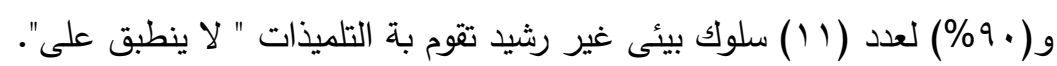

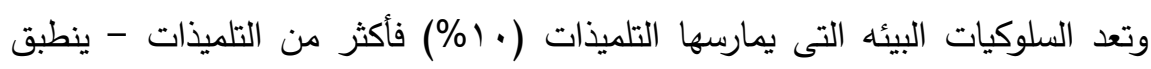

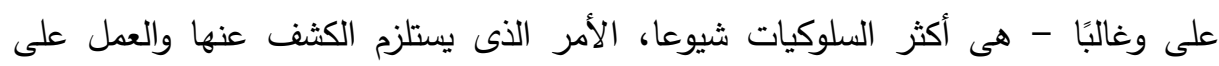

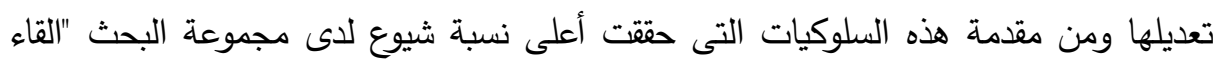

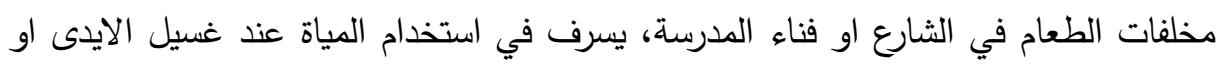

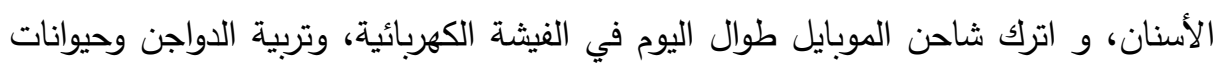

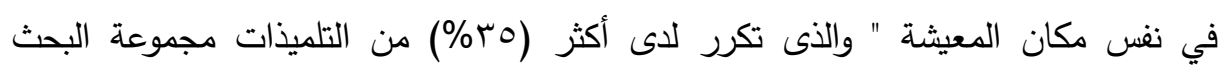

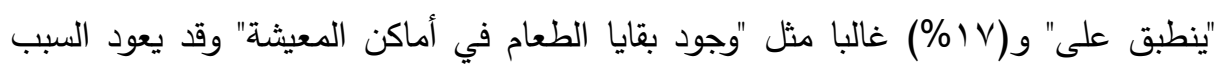

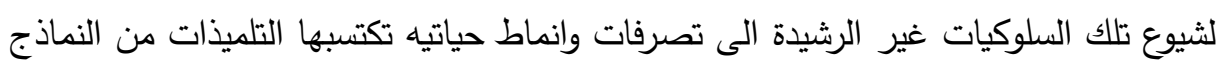

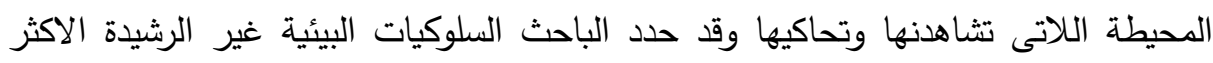

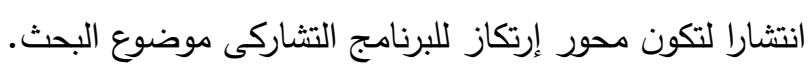
وقد عرضت القائمه على مجموعه من المحكمين في مجال التربيه البيئية. وعدلت

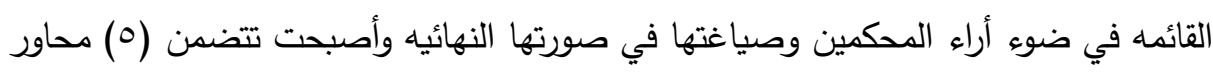
بيئيه هي (سلوكيات مرتبطة بتتاول الطعام والثراب، سلوكيات مرتبطة بالحياة اليومية

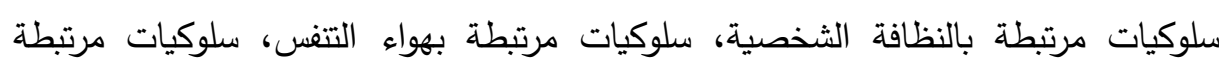
باللعب). ثانياً: اعداد برنامج الأنثطة البيئية القائم على التعلم التشاركى الاكترونى لتصويب بعض السلوكيات نحو البيئه.

1-فلسفة البرنامج: يقوم البرنامج على فلسفة قائمة على توظيف الادوات التشاركية الالكترونية

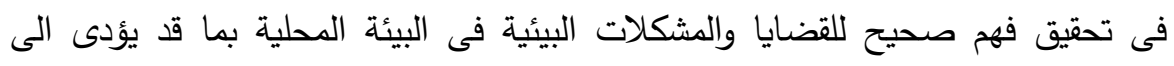
تصويب بعض السلوكيات الغير رشيدة تجاة البيئة للتلميذات مجموعة البحث.

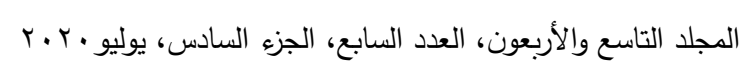


مجلة العلوم البيئية

معهد الدراسات والبحوث البيئية - جامعة عين شمس لبئه

احمد احمد عبد القدوس وآخرون

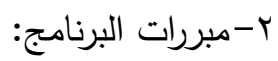

ه انتشار السلوكيات البيئية الغير رشيدة بين تلاميذ المرحلة الاعدادية.

شكوى الاخصائيين والمدرسين فى المدرسة من السلوكيات الغير رشيدة تجاة البيئة

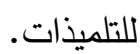

شكاوى اولياء الامور من الاسراف المتذايد فى الاستهلاك.

• قلة الانشطة الاككترونية المتعلقة بالبيئة.

r-الهدف الرئيس من البرنامج: تعديل بعض السلوكيات البيئية في الواجهه المرغوبة، وتقوية السلوك الرشيد تجاة البيئه وأضعاف السلوك غير الرشيد، ويستند تتفيذ النشاط الى نظئ نظرية التعلم لسكينر فركز على سلوك الفرد في الحاضر وتفاعلة مع البيئه الحاضرة، اى أنه يهتم بما يفعلة التلميذ/ة الان وبصورة مباشرة ودقيقة وكيف تؤثر افعالة على البيئه بصورة

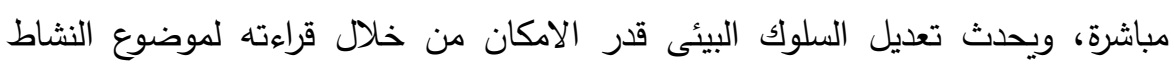

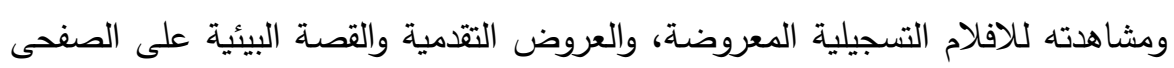
التجريبية على موقع (Edmodo) تحت اشراف الباحث، ويتترح بعض الحلول أو ابتكار بعض التجارب أو مشاركة ابحاث تقوم المجموعة بنشرها تدعو الى الاقلاد من السلوكيات البيئية غير المرغوبة الى بدورها تساعد في الحد من التلوث البيئى. وفي ضوء هذا الهدف تم تحديد الأهداف العامة الآتية:

• إعداد المتعلم الذي يمتلك القدرة على تمييز السلوك الرشيد وغير الرشيد تجاه البيئه. • تمية ودعم بعض السلوكيات البيئية الرشيدة للتلاميذ باستخدام بعض الأنشطة التشاركية.

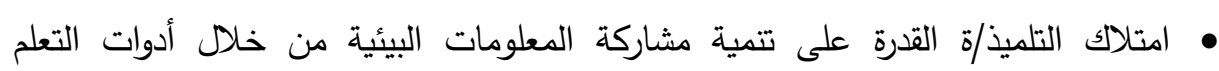
التشاركي. • معرفة أهمية البيئه وأساليب المحافظة عليها من خلال الادراك للسلوكيات الرشيد تجاه البيئه 


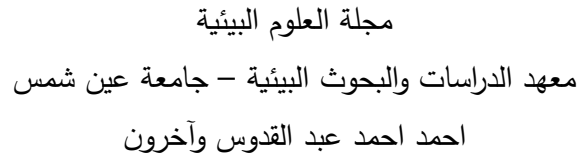

إكساب المتعلم السلوكيات البيئية الرشيدة ذات العلاقة بالقضايا والمشكلات البيئية المحلية.

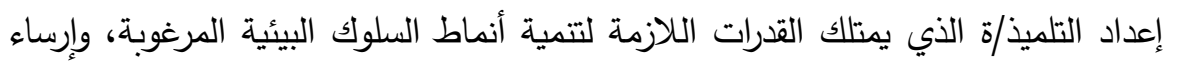
قواعد الأخلاقيات البيئية السليمة. اكساب المتعلم الطرق المثلى لحل المشكلات البيئية الموجودة في بيئته ليقف على أهم مسبباتها خاصة المسببات الناتجة عن السلوكيات غير رشيدة تجاه البيئه.

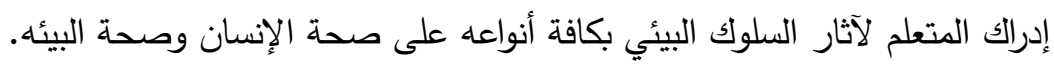
المساهمة في تعديل السلوك البيئي غير الرشيد تجاه البيئه من خلال التعلم التشاركي لإنياني الإككتروني كما يوضحه مقياس تعديل السلوك المقترح بأبعاده المختلفة حول الموضوعات المئي المقترحة.

ع-مكونات البرنامج: تم اختيار عناصر برنامج الانشطة في ضوء القائمة النهائية للسلوكيات

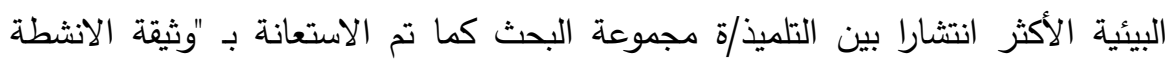
البيئية والسكانية والصحية نحو تحقيق تنمية مستدامة" والصادرة من ادارة التربية البيئية

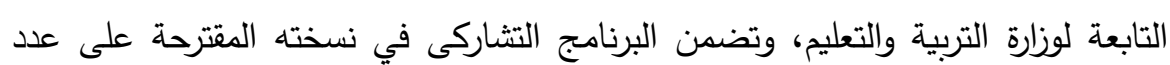

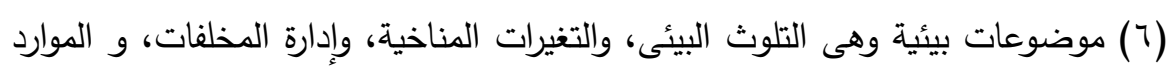

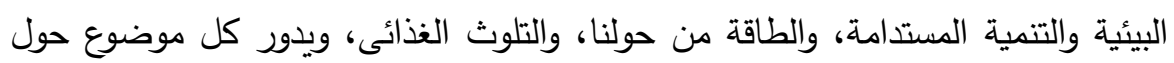

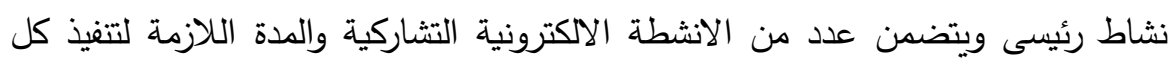
نشاط مع مجموعة البحث عبر منصة (Edmodo) التشاركية، ويوضح الجدول (0) مكونات البرنامج الأنشطة التشاركية والمده الزمنيه له. 
مجلة العلوم البيئية

معهد الدراسات والبحوث البيئية - جامعة عين شمس لبئه

احمد احمد عبد القدوس وآخرون

جدول (•): مكونات البرنامج الأنشطة التشاركية والمده الزمنيه له

\begin{tabular}{|c|c|c|c|}
\hline الخطه الزمنيه & عنوان النشاط & محور النشاط & اليوم \\
\hline 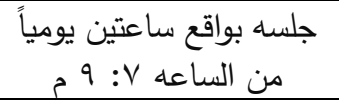 & في بيئتنا خطر & التلوث البيئى & الاول \\
\hline 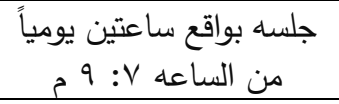 & الكوكب الحار & التغيرات المناخية & الثانى \\
\hline 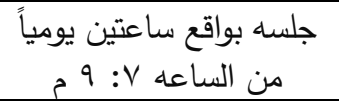 & الصورة بتتكلم & إدارة المخلفات & الثالث \\
\hline 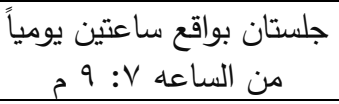 & • • • •الانسان تكلفنى عاداتى الماء & والتتمية المستدامة البيئة & 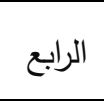 \\
\hline 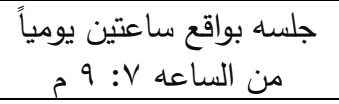 & الطاقة من حولنا & الطاقة من حولنا & الخامس ل \\
\hline 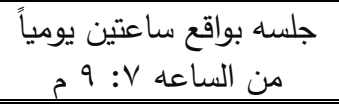 & وجبة صحية نظيفة & التلوث الغذائى. & السادس \\
\hline
\end{tabular}


مجلة العلوم البيئية

معهد الدراسات والبحوث البيئية - جامعة عين شمس لبه

احمد احمد عبد القدوس وآخرون

\begin{tabular}{|c|c|c|c|}
\hline \multicolumn{4}{|c|}{ جدول (†): الجمل المعبرة عن السلوك غير الرشيد محور إرتكاز البرنامج } \\
\hline 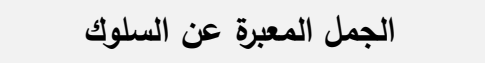 & s & الجمل المعبرة عن السلوك & s \\
\hline أتزك ما تبقى من طعام مكثوفا بعد & 17 & مشاركة زملائي في تنظيف فناء المدرسة. & 1 \\
\hline 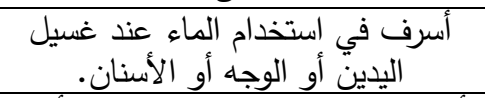 & iv & يرتبط تلوث البيئة بالغازات المنبعثة من السيارات. & r \\
\hline أرفع صوت التليفزيون بشكل عال أثناء & 11 & أختار الطعام الطازج مثل الفواكه & $r$ \\
\hline أشارك زملاني في المدرسة بكتابة بعض الجدران. & 19 & أستخدم المواد الكميائية في تتظيف المنزل. & $\varepsilon$ \\
\hline 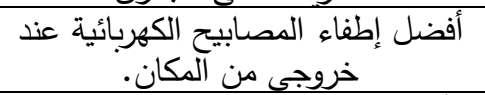 & r. & أغلق الباب أو ألثيفيف عند التشغيل. استخدام المدفأة & $\bullet$ \\
\hline أترك شاحن الموبايل طوال اليوم في الكهربئية. & YI & ينبغي زيادة المبيدات الحشرية في المنزل & 7 \\
\hline أتتاول الخبز غير المغطى والمعرض الهواء. & rt & أستمتع بقطف الأزهار وإهدائها. & V \\
\hline ألقي مخلفات الطعام في الثارع أو في & r & يزعجني منظر المخلفات في الشوارع & $\wedge$ \\
\hline أتناول الخضراوات والفاكهة المعروضة غديل. & $r \varepsilon$ & إنشاء الحدائق المنزلية أمر غير ضروري. & 9 \\
\hline أنام في الحجرات غير متجددة الهواء. & ro & 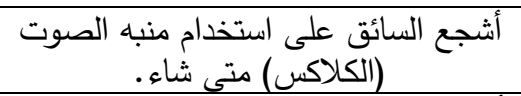 & 1. \\
\hline استعمال سماعات الأذن وسماع الأل بصوت عالِ & $r y$ & أحاول شراء المستعمل من الملابس ولعب الجديد & 11 \\
\hline إهمال غسيل الأسنان. & rV & أشجع على قطع الأشجار إذا كان مبررا. & ir \\
\hline وجود بقايا الطعام في أماكن المعيشة. & $r \wedge$ & عائلتي تستخدم المصابيح الكهربائية & ir \\
\hline تربية الدواجن والحيوانات في مكان & rq & ألقي القمامة في الطريق العام. & $1 \varepsilon$ \\
\hline اللعب بألعاب معاد استخدامها من المخلفات. & r. & أرفع صوتي بشكل مزعج عندما ألعب. & 10 \\
\hline
\end{tabular}

المجلد التاسع والأربعون، العدد السابع، الجزء السادس، يوليو ·. r.

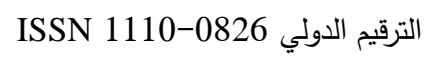




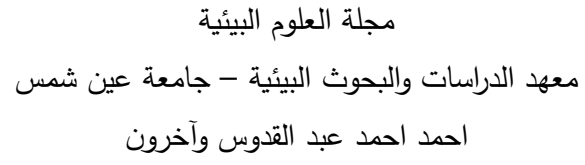

ثالثا: خطوات تأسيس او انثاء منصة (EDMODO) التعليمية لتنفيذ البرنامج التشاركى:

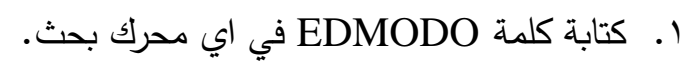
r. بعد اختيار موقع EDMODO يظهر ثلاث اختيارات (المعلم - الطالب - ولى الامر). r. بعد دخول الموقع يتم كتابة البيانات المطلوبة للتسجيل. ؟. اضغط SIGN UP FOR FREE.

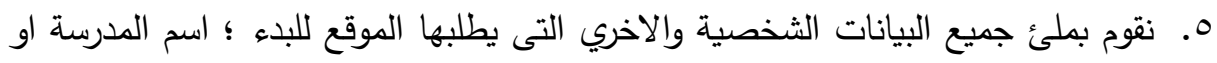
الجامعة - اسم المعلم - اسم المادة -المنطقة او البلد.

7. كيتم استكمال جميع بيانات البروفايل المطلوبة.

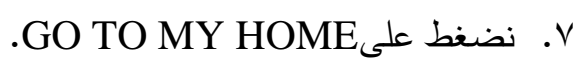
^. بذلك نكون قد أنشأنا المنصة التعليمية؛ ويمكن الان تحميل الثروحات والمواد التعليمية.

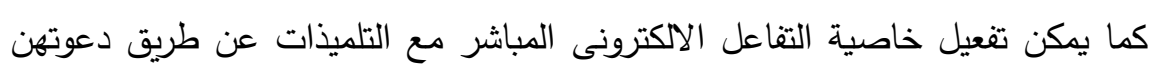
للتشارك بارسال كود الدرس لهن. رابعًا: طريقة سير التعلم التشاركي الإكتروني: في اليوم الأول تم اللقاء بين التلميذات في

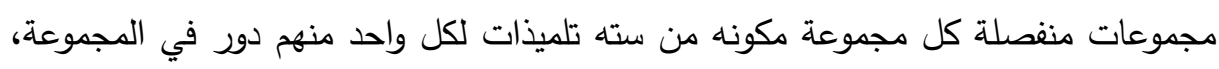

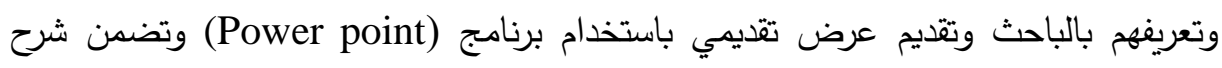

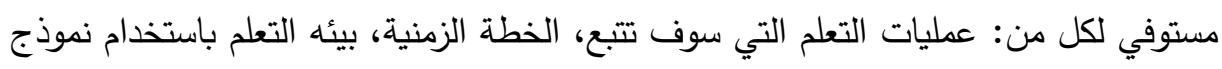
بيئات التعلم المفتوحة (Edmodo)، وطريقة التواصل، وأهمية المشاركة، وتحديد مهام كل فرد

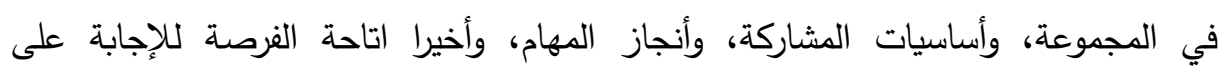
استفسارات التلميذات.

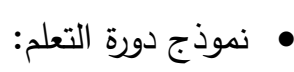

ا-مرحلة التهيئة: تم التعرف على المهمة التعليمية لأول مرة، وتوجيه اهتمام التلميذات الى شيء او مشكلة بيئية اوسلوك بيئي معين، وتم ذلك من خلال طرح سؤال غير مباشر أو 280 المجلد التاسع والأربعون، العدد السابع، الجزء السادس، يوليو • r.r.

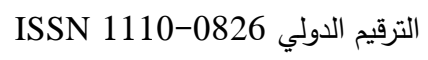




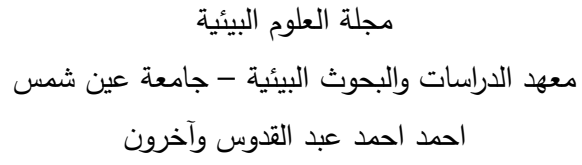

حدث مشير، أو تعريف لمشكلة بيئية أو ترتيب موقف ما بقصد جذب اهتمام التلاميذات للتركيز والاهتمام بالمشكلة البيئية بقصد تحديدها.

ץ-مرحلة الاستكثاف: تم تصميم أنثطة مرحلة الاستكثاف بهدف تزويد التلميذات بقاعدة بالهدئ أساسية تمكنهم من الاستمرار في تتمية بعض السلوكيات غير الرشيدة تجاه البيئه وتكوين خبرات تمكنهم لاحقا في مناقشة المشكلات البيئية، وفي هذه المرحلة يتم توفير خبرات

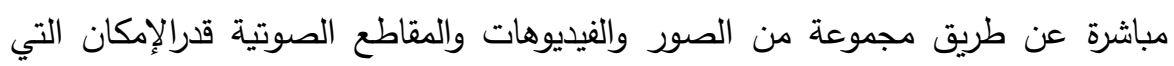

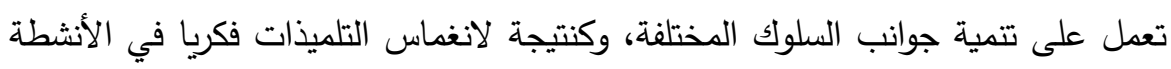

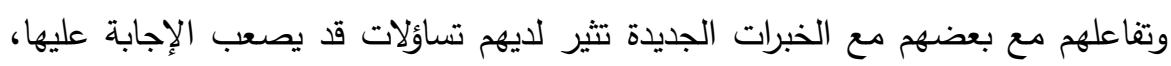

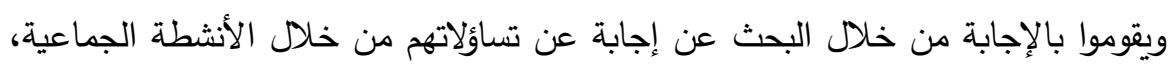

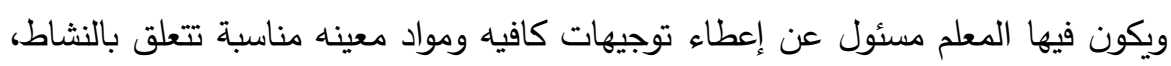
وأتاحه الوقت الكافي والفرصة لاستكثاف المواقف السلوكية بناء على الأفكار التشاركية بين التلميذات.

ب-مرحلة التقسير : في المرحلة هذه تم تزويد الطلبة بالاستيعاب المعرفي حيث وُجه الاهتمام

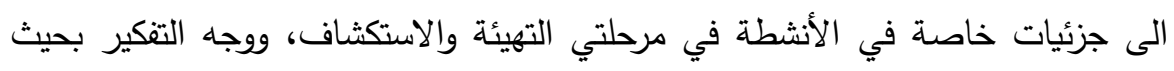

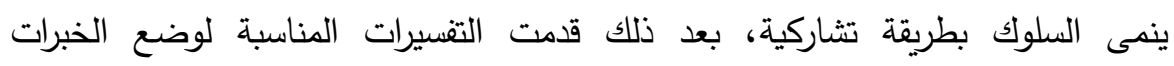
التشاركية في وضعها الصحيح.

ع-مرحلة التعميم: تم التمركز فيها على التلميذات حول مساعدتهن على التظيم العقلي للخبرات التي حصلن عليها وربطها بأفعالهن السلوكية تجاه البيئه، ومساعدتهن على على فئى تطبيق ما تعلموه في مواجهة مشكلات بيئية جديدة تتطلب تفسيرات مماثلة أو متشابهة. 0-دور التلميذات في مرحلة التعلم التثاركى: المساهمة بارائهم حول السلوكيات الغير رشيدة المعروضة من خلال الانشطة للموضوعات المختارة على صفحة الموقع (Edmodo) للوصول الى وجهة نظر واحدة.

$$
\begin{aligned}
& \text { المجلد التاسع والأربعون، العدد السابع، الجزء السادس، يوليو . F. }
\end{aligned}
$$

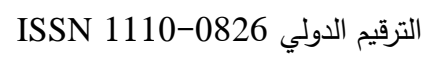


مجلة العلوم البيئية

معهد الدراسات والبحوث البيئية - جامعة عين شمس لبئه

احمد احمد عبد القدوس وآخرون

\begin{tabular}{|c|c|c|}
\hline \multicolumn{3}{|c|}{ جدول (V): دور التلميذات فى التعلم التثاركى } \\
\hline الوصف & 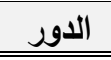 & s \\
\hline تسهيل التواصل مع أفراد الدجموعة، ويقوم بأدارة النقاش وكذلك يحث الأنمال. & 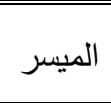 & 1 \\
\hline 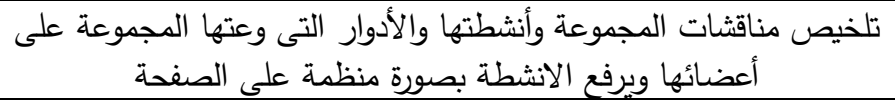 & 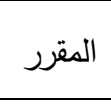 & r \\
\hline هو الثخص المتحدث عن الهجوعة لأستاذ الماده & 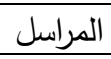 & r \\
\hline 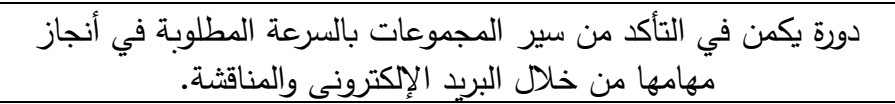 & 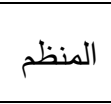 & $\varepsilon$ \\
\hline يثير اعتراضات ليس لانه غير مقتتع بها، ولكن من النوع الذي قد يثيرها & الخصم & 0 \\
\hline تجميع النشاط وصياغتة في صورتة النهائية مع أمكانية طلب المساعدة من & 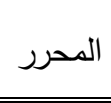 & 1 \\
\hline
\end{tabular}

خامسًا: إعداد دليل المعلم لتنفيذ البرنامج وإثتمل الدليل على العناصر الآتية:

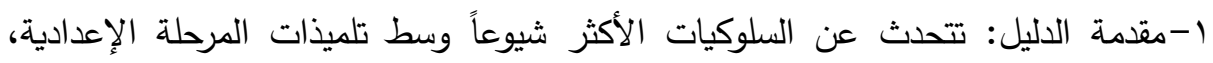
وأهمية استخدام التعلم التشاركي في تتمية السلوك الغير رشيد تجاه البيئه المحيطة لهم ذلك الكيط للوقوف على أساليب تعليمية جديدة.

ץ-هدف الدليل: يهدف الدليل الى مساعدة المعلم على استخدام المنصة الإكترونية في تصويب بعض السلوكيات تجاه البيئه اعتمادا على التعلم التشاركى عبر منصى التصن

(Edmodo)

r-مقدمه البرنامج: وتضمنت مقدمه نظرية مختصره عن طريقة استخدام منصة (Edmodo) التعليمية المنشأة خصيصا للتجربة البحثية ونموذج التعلم البنائى المستخدم في تتفيذ منئه الانشطة. ع - الخطه الزمنية لتنفيذ لقاءات البرنامج. 
مجلة العلوم البيئية

معهد الدراسات والبحوث البيئية - جامعة عين شمس لهـ آلبه

احمد احمد عبد القدوس وآخرون

$$
\begin{aligned}
& \text { 0- إجراءات تتفيذ موضوعات الانشطة: }
\end{aligned}
$$

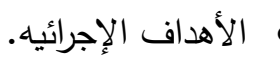

$$
\begin{aligned}
& \text { • جوانب التعلم المرجوه. } \\
& \text { خطوات عرض الموضوعات وتشمل على: }
\end{aligned}
$$

צ-الختام: تضمنت المهام التى تم تكليفها لأفراد المجموعه للتأكد من الوصول الوصل لأهداف

$$
\text { الأنشطة الإلكترونية. }
$$

V- التقويم: الاسئلة المطروحه على تلميذات المجموعه للتأكد من تتمية السلوكيات البيئية عبر منصة (Edmodo) التعليمية.

سادسًا: إعداد أداة القياس:

مقياس السلوك البيئي: الاطلاع على العديد من ادبيات علم النفس البيئي، وعلم النفس العام، وعلم النفس التربوي، والاطلاع على الكثير من الدارسات السابقة التي تتاولت متغيرات البحث الحالي في أحد جوانبه كما هي مبينه في الجانب النظري للبحث، ومنها مشكلات التلوث البيئي، الاهتمام بالقضايا البيئية، وترشيد استخدام الطاقة والمياه فضلا عن الاستفادة، وحماية الثروة الحيوانية، وحماية الغطاء النباتي. الاطلاع على كل ما هو متاح من المقاييس والأدوات ذات العلاقة بموضوع البحث،

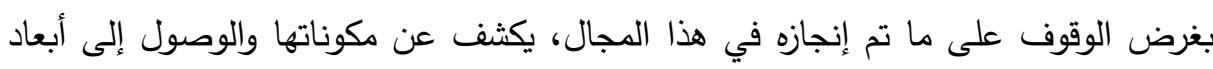

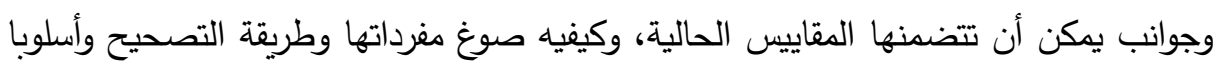

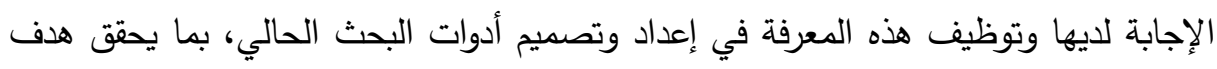

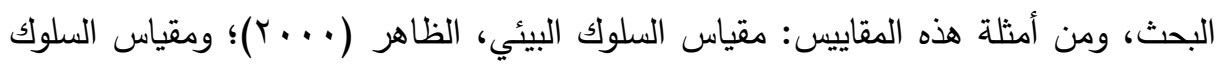

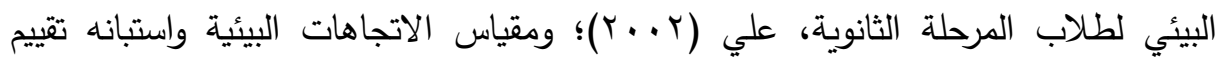

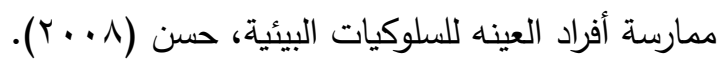

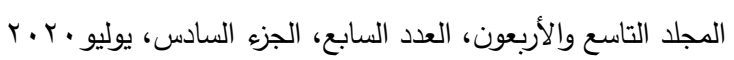

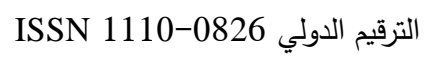




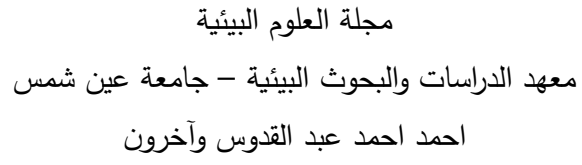

ا. الهدف من المقياس: يهدف المقياس إلي قياس السلوكيات غير الرشيدة تجاة البيئه بين التلميذات، قبل تتفيذ البرنامج للتعرف على مدى التعديل في السلوك بعد تتفيذ البرنامج. r ا . صياغة بنود المقياس:

•القسم الأول: تضمن وصف المقياس، وتوضيح الهدف منه، ومتغيرات البحث والمرحلة الدراسية. • القسم الثانى (كتابة بنود المقياس): حاول الباحث عند اختياره لبنود المقياس، أن تكون

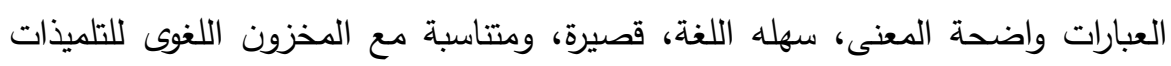
عينه البحث في المرحلة الأعدادية. يحتوى المقياس على (•r) عبارة يمثل كل منها سلوك بيئى محدداً، ويلى كل فقرة

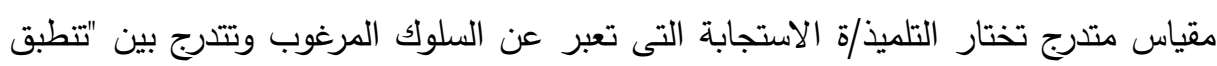

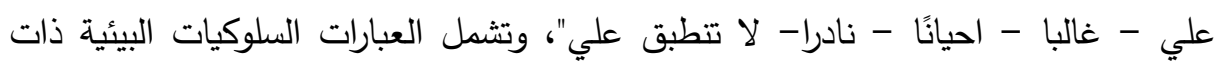

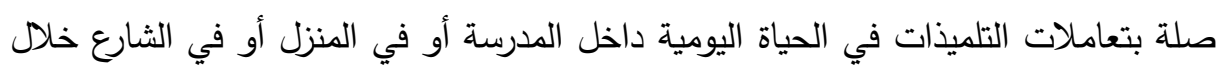
الممارسات اليومية للتلميذات. r. طريقة الأجابة على المقياس: تعتمد الاجابة على بنود المقياس على اسلوب التقدير

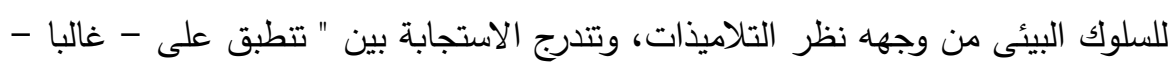

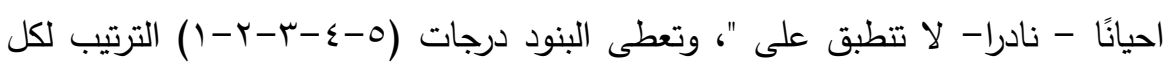
بند، يستجيب المفحوص لها يوضع علامة (x) تحت البديل المناسب من بدائل مقياس

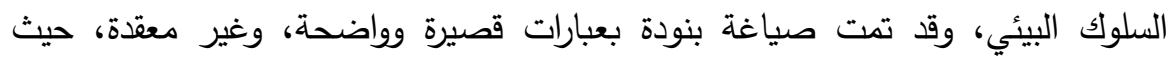
تتتاسب مع مستوى التلميذات العمرى، والاجتماعى، والثقافي، حتى لا تستغرق التلميذات وقت طويل في الاجابة عليها. 
مجلة العلوم البيئية

معهد الدراسات والبحوث البيئية - جامعة عين شمس لبئه

احمد احمد عبد القدوس وآخرون

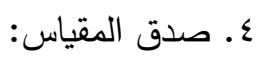

• صدق المحكمين: اعتمد الباحث في التحقق من صدق الادوات طريقة صدق المحكمين، حيث تم عرض مقياس (السلوك البيئى) على مجموعة من الاساتذة ذوى الخبرة

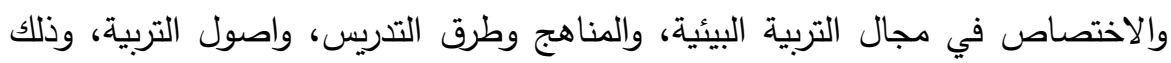
للاستفادة من خبراتهم في الحكم على صحة المقياس ومدى ملائمتة لغرض البحث.

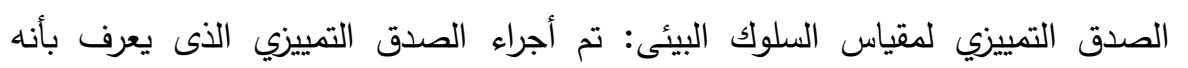

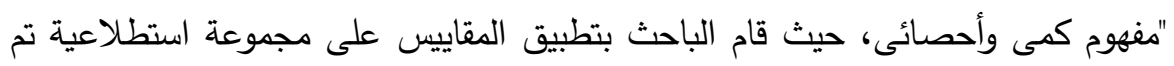
اختيارهم بطريقة عشوائية بلغ عددها (•r) تلميذه للتأكد من صدق الأدوات ولاختبار

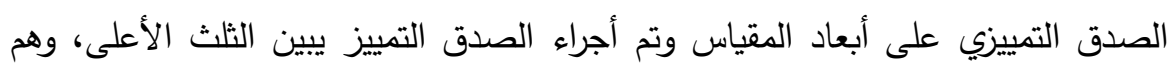
(0) تلميذة من أفراد المجموعة الاستطلاعية، والتلث الأدنى، وهم (10) تلميذة من أفراد التئيل

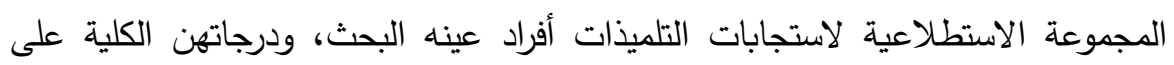

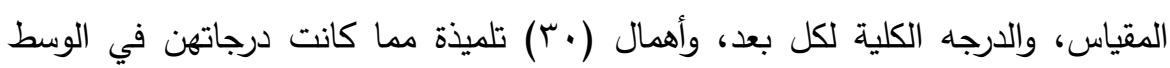

$$
\text { حيث رتبت الدرجات تصاعديا. }
$$

ولحساب الفئة العليا والفئة الدنيا تم استخدام برنامج (SPSS) الاحصائي لحساب

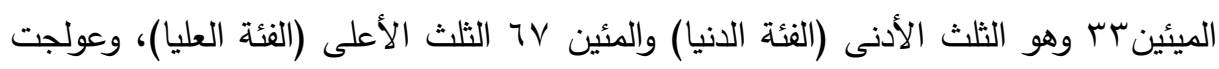

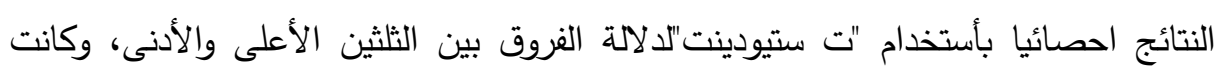

$$
\text { هـ النتائج كمات تثير إليها الجداول. }
$$

- ثبات بالاعادة: قام الباحث على تطبيق مقياس السلوك البيئي على عينه مكونه من (·r) تلميذه، تم استبعادهم في التطبيق الأساسى، وأعاد الباحث تطبيق الاداة على المجموعة بادئ

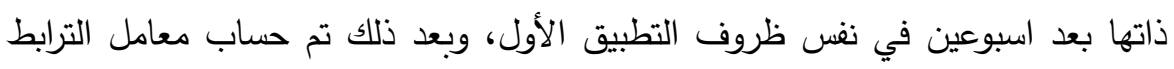
(Bravais-Pearson)

$$
\begin{aligned}
& \text { المجلد التاسع والأربعون، العدد السابع، الجزء السادس، يوليو . r. }
\end{aligned}
$$

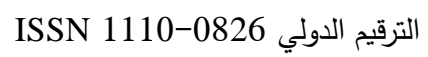




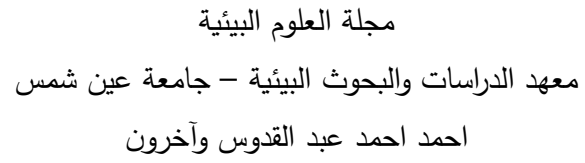

- الثبات بالاتساق الداخلى: قام الباحث بحساب الاتساق الداخلى من خلال حساب قيمة

(Cronbach's alpha)

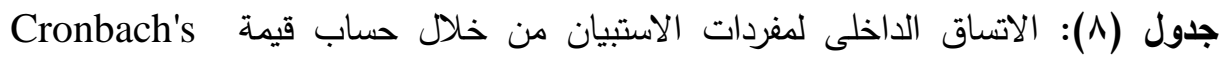
alpha

\begin{tabular}{|c|c|c|}
\hline \multicolumn{3}{|c|}{ Reliability Statistics } \\
\hline \hline No. of Items & $\begin{array}{c}\text { Cronbach's Alpha Based on } \\
\text { Standardized Items }\end{array}$ & Cronbach's Alpha \\
\hline 30 & .981 & .981 \\
\hline \hline
\end{tabular}

المقياس في صورته النهائيه: عقب الإنتهاء من الخطوات السابقه تم صياغة المقياس في صورته النهائيه، وبعد عرضه على المحكمين، أصبح المقياس في صورته النهائيه مكونا من النيه

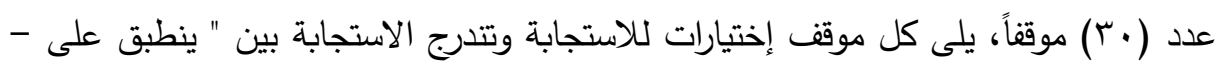

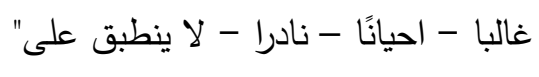

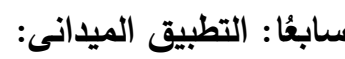

1-أجراءات تطبيق ادوات البحث: وتمثلت بالحصول على موافقة وزارة التربية والتعليم ومديرية التربية والتعليم بمحافظة القاهرة وادارة المرج التعليمية بهدف تسهيل مهمة الباحث في في تطبيق مقياس بحثة وتم توزيع المقياس على الطلبة في المدرسة وجرى التطبيق في الفصل

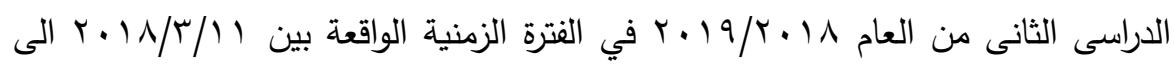

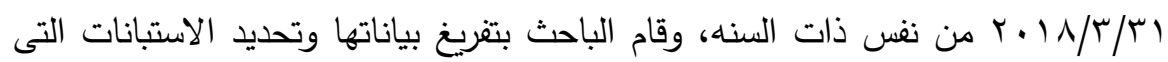
استبعدت لعدم صلاحيتها. ץ-إختيار مجموعة البحث: أعتمد الباحث على اختيار مجموعة من تلميذات مدرسة الشرفاء الاعدادية للبنات بمحافظة القاهرة وهى المدرسة الى كان فى الامكان تطبيق برنامج البحث على تلميذاتها. 


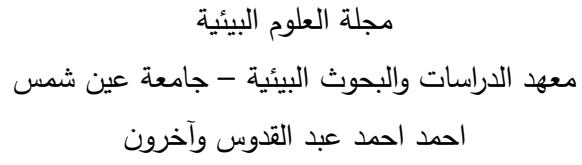

r-التطبيق القبلي لأدوات البحث: تم تطبيق أداه البحث (مقياس السلوك البيئى) قبلياً على

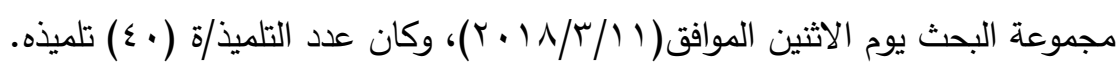

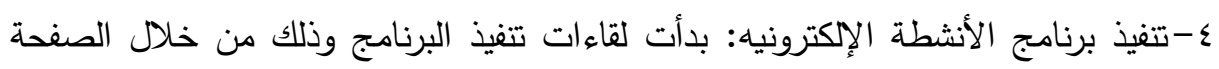

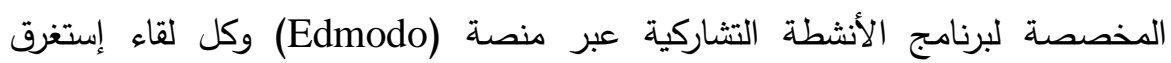
ساعتين يومياً. 0- لأسلوب الإحصائي المستخدم: استخدم الباحث برنامج (SPSS) لحساب: • • م المتوسط الحسابي والانحراف المعياري. هعامل الارتباط.

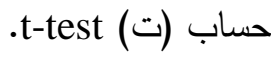
معامل ثبات ألفا كرونباخ والتجزئة النصفية. مربع إيتا، حساب قيمة حجم التأثير (d).

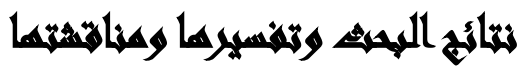

أولاً: نتيجة إختبار صحة فرض البحث، والذي ينص على انه: يوجد فرق دال إحصائيًا

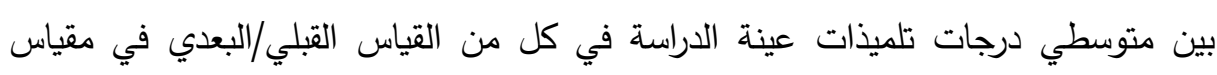
السلوك البيئى لصالح القياس البعدي.

وللتحقق من صحة هذا الفرض تم عمل مقارنه بين متوسطات درجات تلميذات عينة الدراسة في كل من القياس القبلي/البعدي في مقياس السلوك البيئى المتضمن لدحاورالبرنامج وهي: (سلوكيات مرتبطة بتتاول الطعام والثراب، وسلوكيات مرتبطة بالدياة اليومية، وسلوكيات مرتبطة بالنظافة الثخصية، وسلوكيات مرتبطة بهواء التنف، وسلوكيات مرتبطة

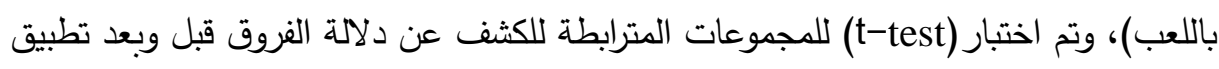
برنامج الأنثطة الإكترونيه البيئية عبر منصة (tEdmodo) التثاركية بعد التأكد أن البيانات

$$
\begin{aligned}
& \text { المجلد التاسع والأربعون، العدد السابع، الجزء السادس، يوليو . r. }
\end{aligned}
$$

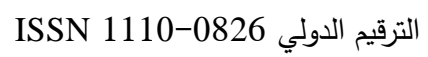


مجلة العلوم البيئية

معهد الدراسات والبحوث البيئية - جامعة عين شمس لبه آلبه

احمد احمد عبد القدوس وآخرون

تتبع التوزيع الطبيعي.

جدول (9): نتائج القياس القبلي / البعدي لعينة الدراسة في مقياس السلوكيات البيئيه

\begin{tabular}{|c|c|c|c|c|c|c|c|c|}
\hline \multirow{2}{*}{ مستوى } & \multirow{2}{*}{ قيمه } & \multicolumn{2}{|c|}{ التطبيق البعدى } & \multicolumn{2}{|c|}{ التطبيق القبلى } & \multirow{2}{*}{ الكلية } & \multirow{2}{*}{ الدام العبارات المقى الدقاس } & \multirow{2}{*}{ أبعقاد } \\
\hline & & المعرافى & المتوسط & الانحراف & المتوسط & & & \\
\hline $\begin{array}{l}0.001 \\
\text { داله }\end{array}$ & 0.014 & 2.582 & 78 & 2.63 & 83.25 & 150 & $1 / 2 / 4 / 5$ & والثناول \\
\hline $\begin{array}{l}0.001 \\
\text { داله }\end{array}$ & 0.105 & 3.736 & 79.8 & 4.517 & 82.2 & 150 & $\begin{array}{c}3 / 9 \\
10 / 11 / 12 \\
15 / 16 \\
17 / 24 / 27 \\
\end{array}$ & اليومية \\
\hline $\begin{array}{l}0.001 \\
\text { داله }\end{array}$ & 0.009 & 4.106 & 76 & 6.234 & 83 & 150 & $\begin{array}{c}13 / 14 / 18 / \\
19 / 20 / 21 \\
\mid 22 / 23\end{array}$ & الثخصية \\
\hline $\begin{array}{l}0.001 \\
\text { داله }\end{array}$ & 0.248 & 5.586 & 76.8 & 5.07 & 79.2 & 150 & $\begin{array}{c}6 / 7 / 8 / 25 / \\
26\end{array}$ & التنفس \\
\hline $\begin{array}{l}0.001 \\
\text { داله }\end{array}$ & 0.5 & 3.512 & 75.4 & 3.055 & 79.67 & 150 & $28 / 29 / 30$ & اللعب \\
\hline
\end{tabular}

يتضح من نتائج الجدول السابق ما يلي:

• توجد فروق ذات دلالة احصائية عند نسبة شك (0., •) بين الاختبار القبلى والبعدى لبعد (تتاول الطعام والثراب) حيث أظهرت نتائج الجدول السابق أن المتوسط الحسابي للقئ القياس البعدي والذي قيمته تساوي (9^) أكبر من المتوسط الحسابي للقياس القبلي والذى قيمته

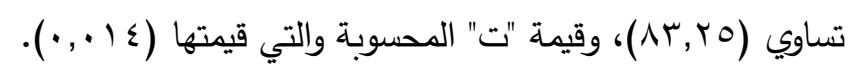




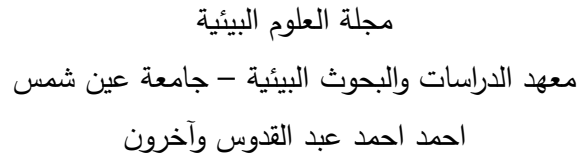

• توجد فروق ذات دلالة احصائية عند نسبة شك (0. , ·) بين الاختبار القبلى والبعدى لبعد

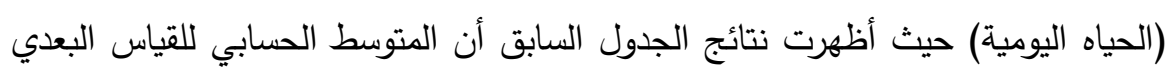
والذي قيمته تساوي (r, r. أكبر من المتوسط الحسابي للقياس القبلي والذى قيمته تساوي

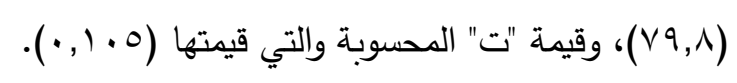

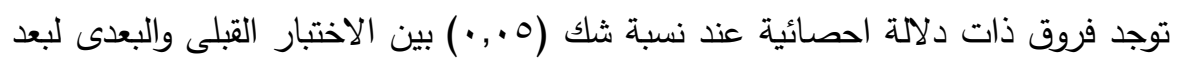
(النظافة الثخصية) حيث أظهرت نتائج الجدول السابق أن المتوسط الحسابي للقياس البعدي والذي قيمته تساوي (r^) أكبر من المتوسط الحسابي للقياس القبلي والذى قيمته

$$
\text { تساوي (VT)، وقيمة "ت" المحسوبة والتي قيمتها (9 ( . ., .). }
$$

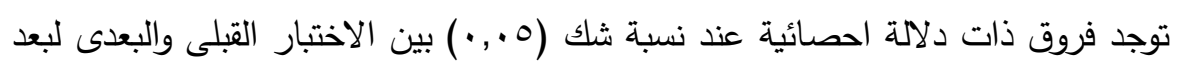
(هواء التنفس) حيث أظهرت نتائج الجدول السابق أن المتوسط الحسابي للقياس البعدي

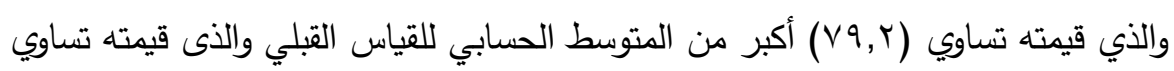

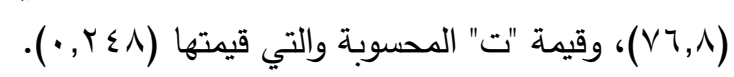

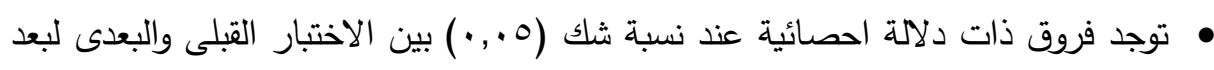
(اللعب) حيث أظهرت نتائج الجدول السابق أن المتوسط الحسابي للقياس البعدي والذي دئي

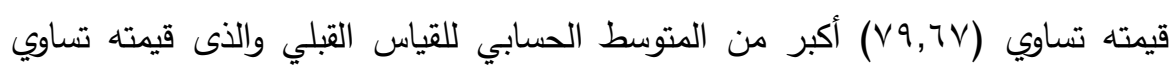

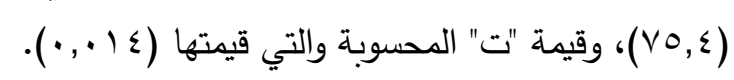

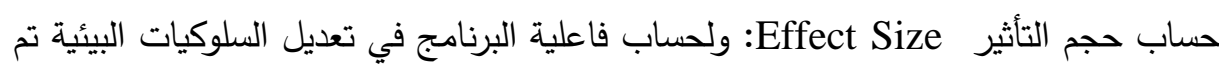
حساب حجم التاثير عن طريق مقارنه نتائج قيم "ت" المحسوبة لنتائج تلميذات عينة الدراسة

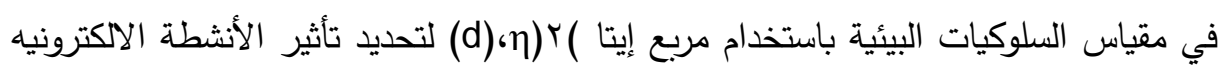
في التطبيق البعدي لمقياس السلوكيات البيئية. 
مجلة العلوم البيئية

معهد الدراسات والبحوث البيئية - جامعة عين شمس لبئه

احمد احمد عبد القدوس وآخرون

جلول ( • (): حجم التاثير ودلالتها لمقياس السلوكيات البيئية

\begin{tabular}{|c|c|c|c|c|c|}
\hline دلالة حجم التأثير & d & $\left(\eta^{r}\right)$ & قيمة "ت" المحسوبة & درجة الحرية & ابعاد المقياس \\
\hline كبير & r,T & $\cdot, \wedge \mathrm{V}$ & $0, \cdot 1$ & rA & المقياس ككل \\
\hline
\end{tabular}

يتضح من الجدول السابق ما يلى: أن (AV,,·) من التباين الكلى للمتغير التابع

(السلوكيات البيئيه غير الرشيدة) يرجع إلى المتغير المستقل (التعلم التشاركى الإكترونى) وجميع هذه القيم أعلى من 0 ا, •.

أن حجم تأثير التعلم التشاركى الاكترونى للأنشطه الالكترونيه المقدمة من خلال منصة

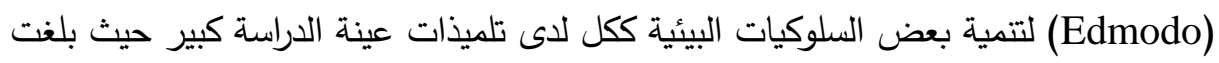

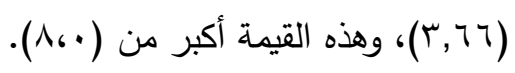

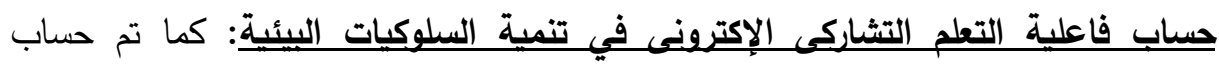
الفاعلية باستخدام معادلة الكسب المعدل لبليك، ويكون للنظام فاعلية اذا حصل على مستوى الإكيروئ

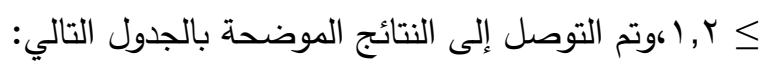
جدول (1 1 ): نسبة الكسب المعدلة تلميذات عينة الدراسة في مقياس السلوكيات البيئيه لدى بلى بالئ تلاميذ المرحلة الاعدادية

\begin{tabular}{|c|c|c|c|c|}
\hline نسبة الكسب & الانحراف المعيارى & المتوسط الحسابى & الالارجة & المجموعة التجريبية \\
\hline \multirow{2}{*}{1,0} & $\varepsilon, 1$ IYQV & Vג, & \multirow{2}{*}{10.} & القياس القبلي \\
\hline & $\varepsilon, \vee 9011$ & $\wedge, \wedge \ldots$ & & القياس البعدى \\
\hline
\end{tabular}

يتضح من الجدول السابق ما يلي: ارتفاع متوسط درجات تلميذات عينة الدراسة في القياس

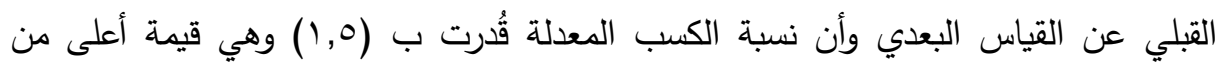

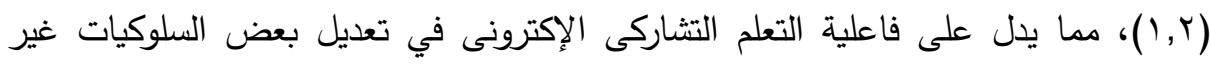
الرشيدة تجاة البيئة.

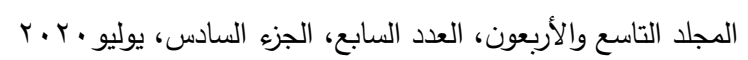

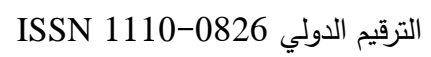


مجلة العلوم البيئية

معهد الدراسات والبحوث البيئية - جامعة عين شمس لبئه

احمد احمد عبد القدوس وآخرون

$$
\text { وقد ترجع نتائج البحث إلي ما يلي:- }
$$

ا-التخطيط الجيد والفعال لموضوعات برنامج الأنشطة الإلكترونيه وتقديمها عبر منصة

$$
\text { (Edmodo) }
$$

r-مراعاة البعد الثقافي والاجتماعى في العملية التثاركية وعدم الاعتماد فقط على البعد المعلوماتى للمحتوى المتبادل عبر منصات التعلم التشاركى.

ب-استخدام العديد من الاستراتيجيات عند عرض المحتوى على الطلاب منها الآتى:

$$
\begin{aligned}
& \text { • استراتيجية العصف الذهنى. } \\
& \text { • استرتيجية لعب الادوار • } \\
& \text { • • استرتيجية فجوة المعلومات. }
\end{aligned}
$$

؟- التتوع في استخدام النصوص والصور والرسوم بشكل مترابط ومتكامل، يجعل المتعلمين

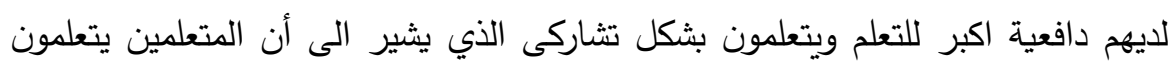

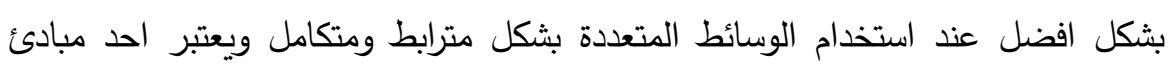
تصميم الأنشطة الإكترونية وفقًا للنظرية البنائيه. وتتثق نتائج البحث الحالي مع نتائج الدراسات التالية:

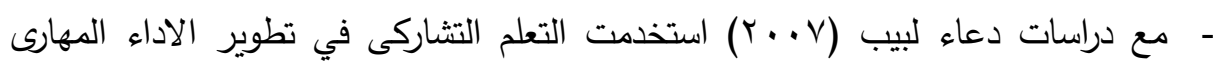
لدارسى الدبلوم العام في التربية.

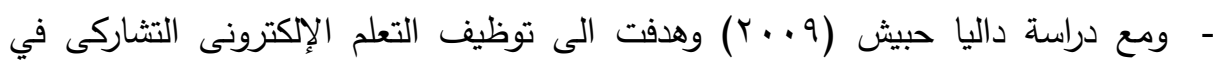
تطوير اداء التدريب الميدانى لدى طلاب شعبة معلمى الحاسب الآلى بكلية التربة النوعية.

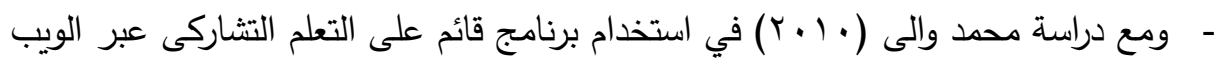

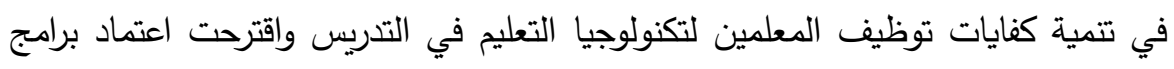
التعلم التشاركى عبر الويب ضمن برامج التدريب المهنى للمعلمين أناء الخدمة.

$$
\begin{aligned}
& \text { المجلد التاسع والأربعون، العدد السابع، الجزء السادس، يوليو • r. }
\end{aligned}
$$

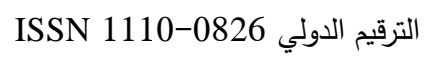




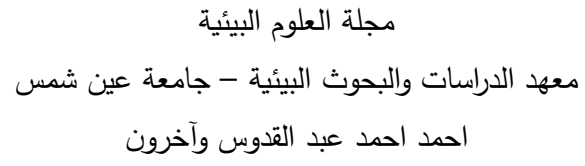

- مدراسة عبد العزيز مطيران (عا • ب) أكدت على أهمية استخدام التعلم التشاركي لتتمية مهارات البحث العلمي الرقمي والتنكير الناقد لدي طلاب كلية التربية الاساسية لدولة الكويت.

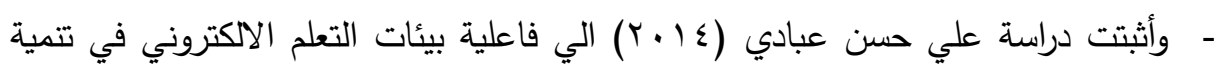
الجانب المهاري لطلاب شعبة تكنولوجيا التعليم في مونتاج الفيديو الرقمي. - أثثتت دراسة Woo \&Li (2011 فاعلية محررات الويب التشاركية في التعلم التشاركي عبر الويب، حيث هدفت هذه الدراسة الي استكثاف التحديات والامكانيات التي تميز استخدام الويكي للتلاميذ والمعلمين في خمس فصول دراسية من فصول اللغة الانجليزية

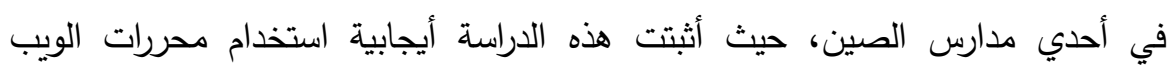

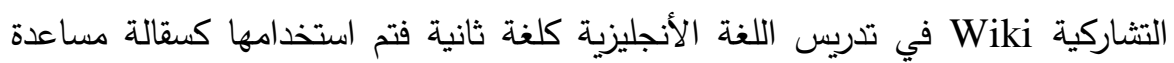

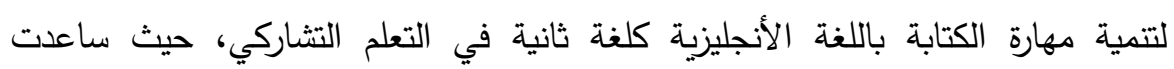
محررات الويب التشاركية Wiki بتسريع عمل المجموعات وتطوير مهارات الكتابة.

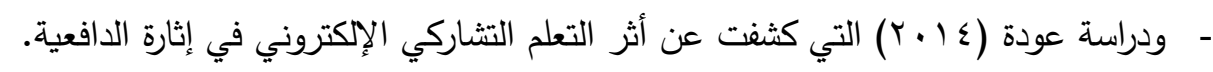

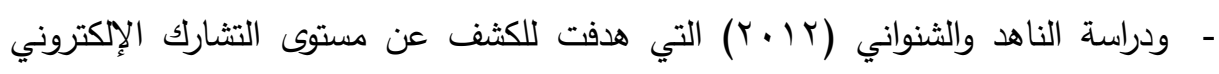
والدافعية في مادة مقدمة في التربية. - ودراسة يوشيدا وتاني وأكيدا وماسيو وناكيما \&oshida, Tani Uchida, Masui, ) (التي تتاولت أثر التعلم التشاركي الإكتروني على تتمية الدافعية نحو تعلم اللغة الكورية في اليابان. - ودراسة بيكلاجي وليفبوسيك (Peklaji \& Levpusck, 2006) التي تتاولت الكثف عن لئن العلاقة بين الدافعية والتحصيل الاكاديمي في مادة علم النفس التي تستخدم استراتيجية التعلم التشاركي الإلكتروني. 


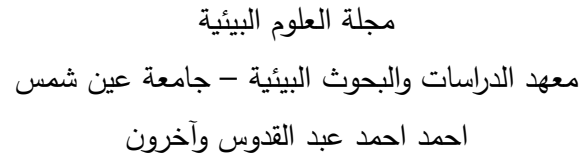

- ودراسة شحروري († ·. - التي حاولت استقصاء فاعلية التعلم التشاركي الالكتروني

$$
\text { المبني على المهارات. }
$$

- وكذلك دراسة جاثري ووايفيلد وفنسكر (Guthrie, Wigfield, Vonesecker,2000) التي هدفت للكثف أثر استخدام استراتيجية التعلم التشاركي الإكتروني في تتمية دافعية الطلبة نحو القراءة لمادة اللغة الإنجليزية.

\section{توكيلما المهيه}

في ضوء ما أسفر عنه البحث الحالي من نتائج، يمكن التوصية بما يلي: • • الأستفادة من البرنامج المقترح فى تصويب السلوكيات البيئية.

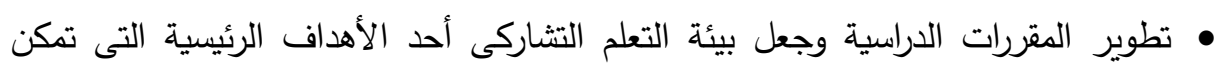
الطلاب من تتفيذ أنشطة التعلم المختلفة. الاستفادة من المواقع التعليمية الإلكترونية التشاركية ومميزاتها في نشر الوعى البيئى

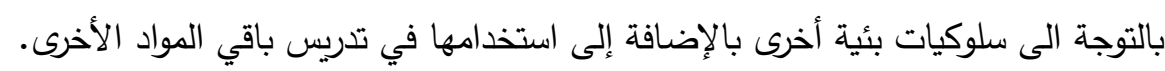

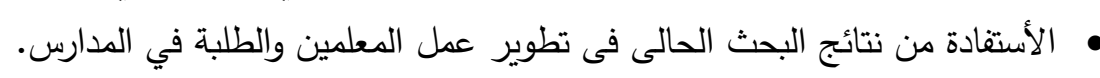

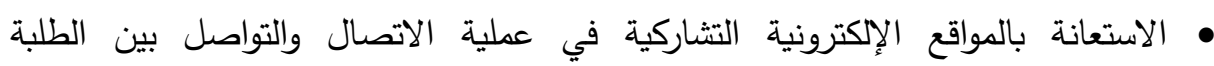
والمعلمين. • عمل ورشات تدريبية للمعلمين والطلبة تتعلق بالتعلم التشاركي الإكتروني.

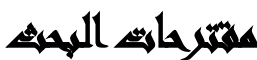

في ضوء ما أسفر عنه البحث الحالي من نتائج، يقترح الباحث:

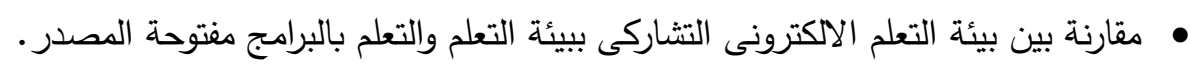
• أثر التفاعلات التعليمية الالكترونية ببيئات التعلم التثاركى فى تتمية الكفائة الذاتية.

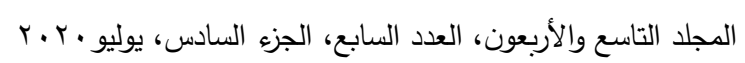

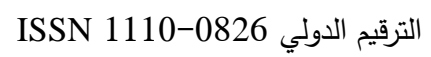




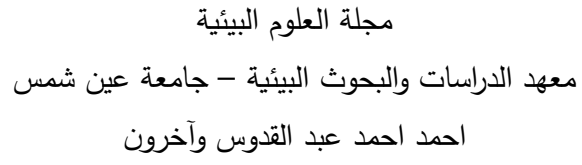

ه أثر التدريس عبر منصة (Edmodo) التعليمية على التحصيل الدراسى وعلاقة ذلك

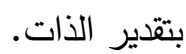

\section{المرانيجة}

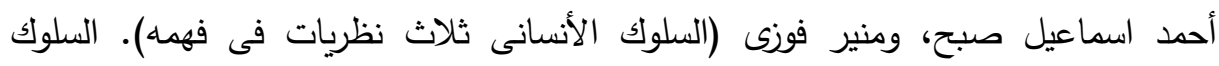

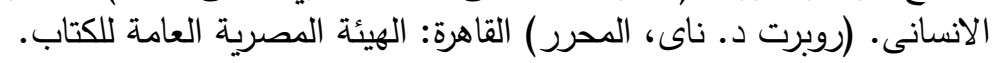

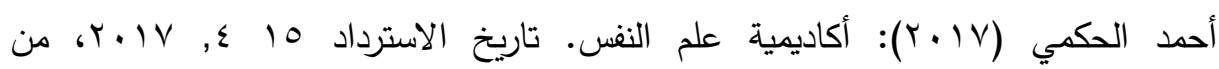
http://acofps.com/vb/showthread.php?t=3123

احمد حسن اللقانى (ץ. . ب): معجم المصطلحات التربوية المعروفة فى المناهج وطرق التدريب. القاهرة: عالم الكتب.

احمد زكى بدوى، وصديقة محمود محمود (999 ()): المعجم العربى الميسر. القاهرة: دار الكتاب المصرى، دار الكتاب اللبنانى.

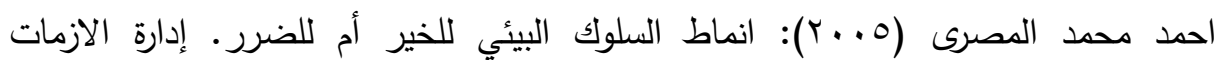

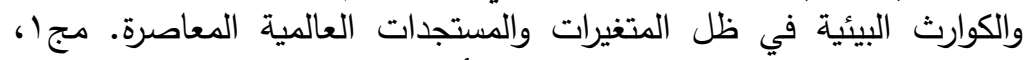

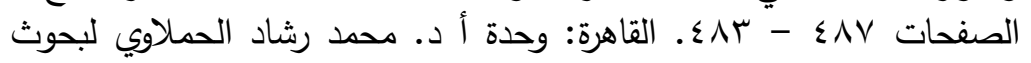
الازمات. كلية التجارة. جامعة عين شمس.

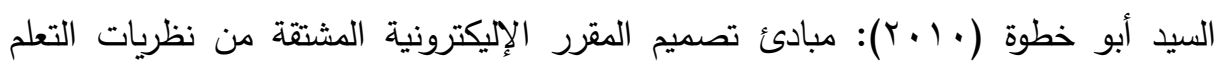

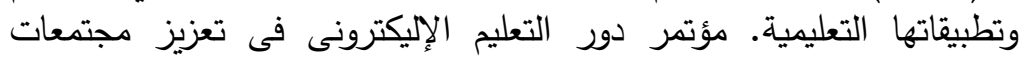
المعرفة. البحرين: مركز زين للتعليم الاليكترونى.

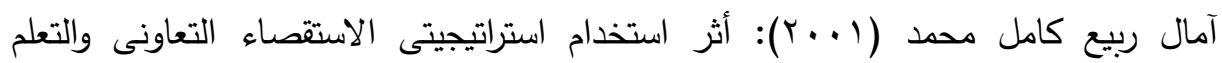

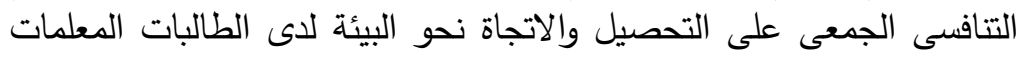
بالتعليم الأساسى (الإصدار r، المجلد ع). القاهرة: مجلة التربية العلمية. أمال هلال ( ا . ب): السلوك الأنسانى والتلوث البيئى. القاهرة: دراسات حول التلوث البيأئى. 


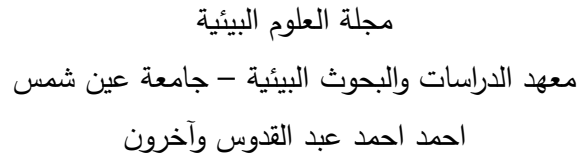

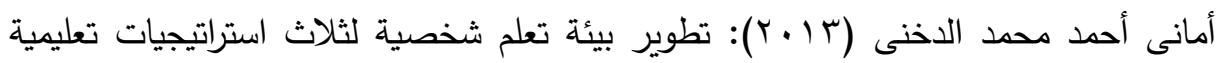
وقياس فاعليتها فى التحصيل وتتمية مهارات التقاعل الاجتماعى. القاهرة.

آية عطية حسن حسين (1) ب. (1): فعالية استخدام الأنشطة البيئية اللاصفية في تتمية المفاهيم

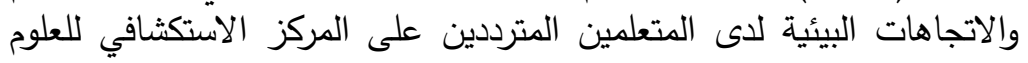

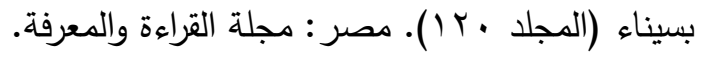

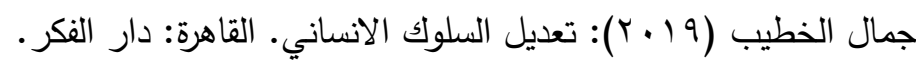

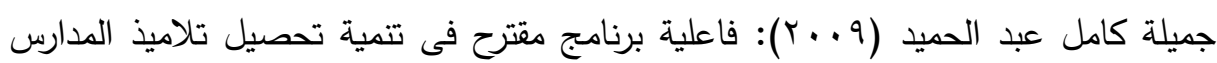

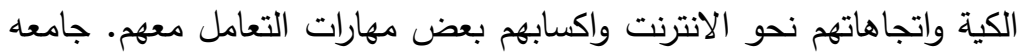
المنيا: كلية التربية.

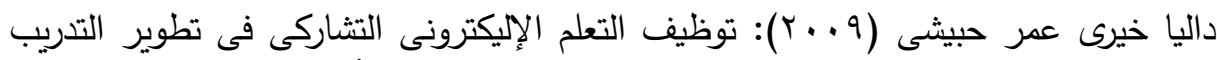

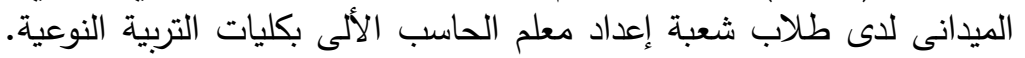
جامعة المنصورة: كلية التربية النوعية.

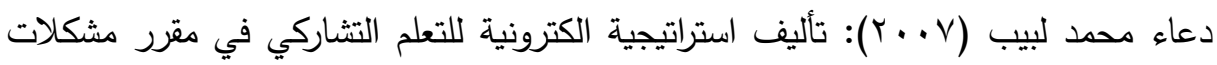

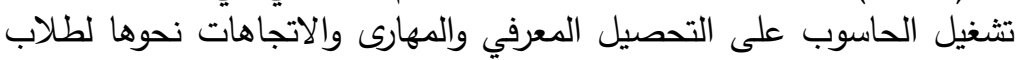
الدبلوم العام في التربية شعبة كمبيوتر تعليمي. جامعة القاهرة: معهد الدراسات

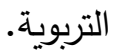

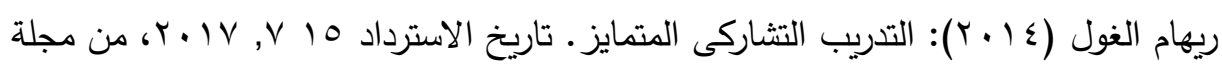
التعليم الاليكترونى: (التبـ

http://emag.mans.edu.eg/index.php?page=news \&task=show $\& \mathrm{id}=463$

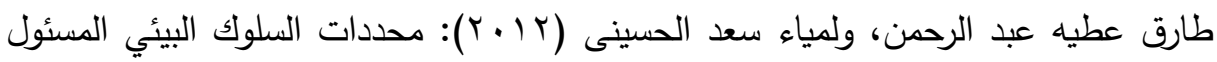

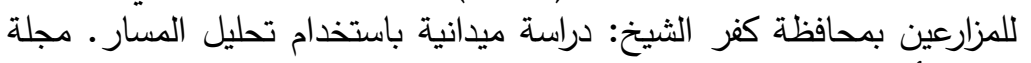

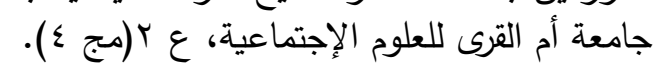

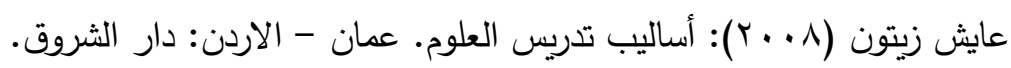




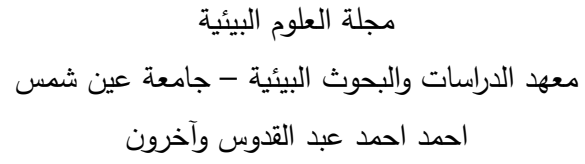

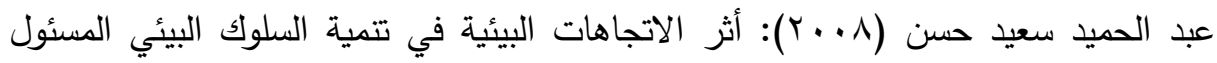

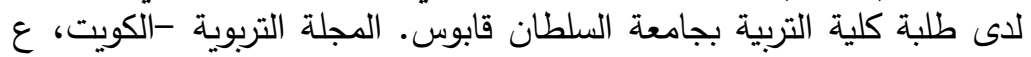

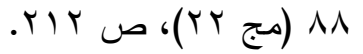

عبد الغني وليد كعكه. (ع . . ץ). معجم مصطلحات "البيئة و التلوث ". أبوظبي: هيئة البيئة.

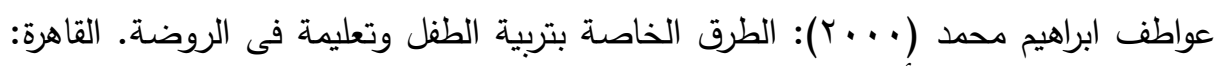
مكتبة الأنجلو المصرية.

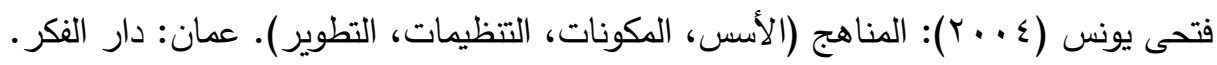

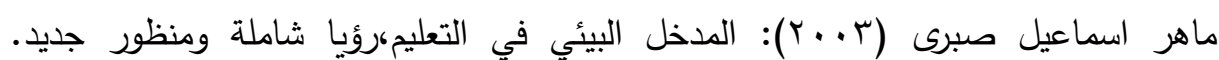

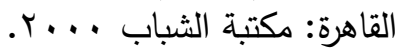

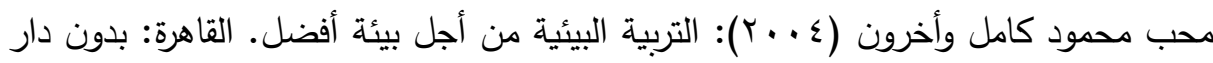
نشر.

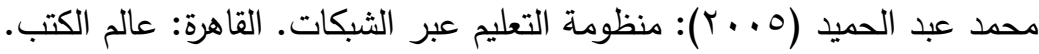

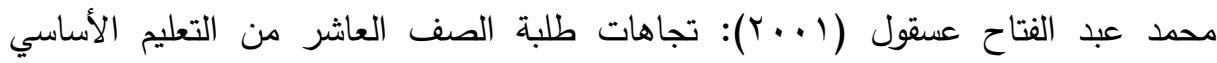
الحكومي في لواء غزة نحو الحاسوب. مجلة الجامعة الإسلامية.

Adelman, P.-K. (2005): Social Environmental Factors And Preteen Health. Social Behavior.

Berger, Milton; Raymond, G. (2001): Principles and Procedures. In M. Berger, \& G. Raymond, Behavior Modification. U.S.: Book.

Gewertz, C. (2012): Common Core Thrusts Llibrarian into Leadrship. Education Week.

Kentucky (2005): Environmental Education Council. Chicago: Annual Report. 


$$
\begin{aligned}
& \text { مجلة العلوم البيئية } \\
& \text { معهد الدراسات والبحوث البيئية - جامعة عين شمس لئل } \\
& \text { احمد احمد عبد القدوس وآخرون }
\end{aligned}
$$

Mouritius, R. O. (2001): Survey or Public Awareness and Attitude Towards The environment. Retrieved from Minister of Environment: http//wwwCsermeng.it/fp/fp914336.htm

Robinson, L. (2005): Annual Report.

Scott, D., \& Willits, F. K. (1994): Environmental Attitudes and Behavior Apennsylvania Survey. Environment and Behavior.

\title{
A PROPOSED PROGRAMME IN ENVIRONMENTAL ACTIVITIES BASED ON E-COLLABORATIVE LEARNING TO CORRECT PREPARATORY SCHOOL STUDENT'S BEHAVIOUR TOWARDS ENVIRONMENT
}

\author{
Ahmed Abdel Koddous ${ }^{(1)}$; Mohamed A. Abdel Fatah ${ }^{(2)}$ \\ Hanan K. Morsy ${ }^{(3)}$ \\ 1) Ministry of Education 2) Faculty of Education, Ain Shams \\ University 3) Faculty of Education, Helwan University
}

\begin{abstract}
The current research aimed at: defining a list of rational and most common environmental behaviours among preparatory stage pupils and knowing the effectiveness of a proposed programme of the environmental activities based on electronic participatory learning to correct these behaviours towards the environment. The current research was limited to the electronic Collaborative activities programme, and

$$
\begin{aligned}
& \text { المجلد التاسع والأربعون، العدد السابع، الجزء السادس، يوليو . r.r. } \\
& \text { الترقيم الدولي 0826- ISSN 1110 }
\end{aligned}
$$




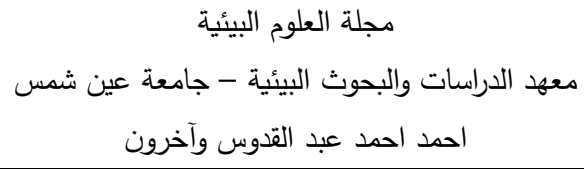

the experimental design was relied upon, The semi-experimental onegroup design was used with the pre and post measurement. The research tools are represented in (a behaviour estimation card) to identify the most prevalent behaviors among pupils, which were (30) behaviours belonging to five environmental axes and (an environmental behaviuor scale) that was applied before implementing the programmme and after applying the programme to know the effectiveness of the proposed programme, and the Arithmetic Average was used, and The "T" test to test the research hypothesis.

The research results showed the effectiveness of the proposed environmental activities programme based on e-collaborative learning in correcting some behaviors towards the environment.

The research recommended the necessity of using the ecollaborative learning environment in the different academic subjects, and the need to prepare training programs for teachers to develop the skill of using the e-collaborative learning environment, and the need to spread awareness of the importance of activating the e-collaborative learning environment because of its effective role in building the educational process and developing achievement.

Key words: E-Collaborative learning, Environmental activities, Irrational environmental behavior. 